\title{
Commercial traceability of Arapaima spp. fisheries in the Amazon basin: can biogeochemical tags be useful?
}

\author{
Luciana A. Pereira ${ }^{1}$, Roberto V. Santos ${ }^{1}$, Marília Hauser ${ }^{2}$, Fabrice Duponchelle ${ }^{3}$, Fernando Carvajal ${ }^{4}$, \\ Christophe Pecheyran ${ }^{5}$, Sylvain Bérail ${ }^{5}$, and Marc Pouilly ${ }^{3}$ \\ ${ }^{1}$ Laboratorio de Geochronologia, Universidade de Brasília, Brasília, 70910-900, Brazil \\ ${ }^{2}$ Laboratory of Ichthyology and Fishery, Department of Biology, Universidade Federal de Rondônia, Porto Velho, Brazil \\ ${ }^{3}$ Institut de Recherche pour le Développement, IRD, Unité Mixte de Recherche "Biologie des Organismes et Écosystèmes \\ Aquatiques" (UMR BOREA - MNHN, CNRS-7208, UPMC, UCBN, IRD-207), 75005 Paris, France \\ ${ }^{4}$ ULRA, Universidad Mayor de San Simon, Cochabamba, Bolivia \\ ${ }^{5}$ Université de Pau et des Pays de l'Adour/CNRS, LCABIE-IPREM, Technopôle Helioparc, 64053 Pau Cedex 09, France
}

Correspondence: Luciana A. Pereira (lualvesp.bio@gmail.com)

Received: 5 November 2018 - Discussion started: 10 December 2018

Revised: 18 February 2019 - Accepted: 5 March 2019 - Published: 26 April 2019

\begin{abstract}
The development of analytical tools to determine the origin of fishes is useful to better understand patterns of habitat use and to monitor, manage, and control fisheries, including certification of food origin. The application of isotopic analyses to study calcified structures of fishes (scales, vertebrae, and otoliths) may provide robust information about the fish geographic origin and environmental living conditions. In this study, we used $\mathrm{Sr}$ and $\mathrm{C}$ isotopic markers recorded in otoliths of wild and farmed commercialized pirarucu (Arapaima spp.) to evaluate their prediction potential to trace the fishes origin. Wild and farmed fish specimens, as well as food used for feeding pirarucu in captivity, were collected from different sites. Isotope composition of otoliths performed by isotope-ratio mass spectrometry (IRMS; $\delta^{13} \mathrm{C}$ ) and femtosecond laser ablation multi-collector inductively coupled plasma mass spectrometry (LAfs-MCICPMS; ${ }^{87} \mathrm{Sr} /{ }^{86} \mathrm{Sr}$ ) were compared to the isotopic composition of water and of the food given to the fishes in the farms. Wild fish specimens that lived in environments with the largest fluctuation of river water $\mathrm{Sr}$ isotope ratios over time presented the largest $\mathrm{Sr}$ isotope variations in otoliths. A quadratic discriminant analysis on otolith isotopic composition provided $58 \%$ of correct classification for fish production (wild and farmed) and $76 \%$ of correct classification for the fish region. Classification accuracy for region varied between $100 \%$ and $29 \%$ for the Madeira and the Lower Amazon fishes, respectively. Overall, this preliminary trial is not
\end{abstract}

yet fully developed to be applied as a commercial traceability tool. However, given the importance of Arapaima spp. for food security and the generation of economic resources for millions of people in the Amazon basin, further analyses are needed to increase the discrimination performance of these biogeographical tags.

\section{Introduction}

Food production is becoming increasingly associated with sustainable practices ensuring environmental preservation goals. Food origin and production conditions have become important issues in national and international trade to attest to adequate practices. For instance, consumers want to know whether the fishes belong to an endangered or vulnerable species and whether they were grown in natural or farmed conditions (Baffi and Trincherini, 2016; Kim et al., 2015; Pracheil et al., 2014). In order to address some of these questions, and further improve wild and farming fish management, recent studies have used biogeochemical tracers to better understand fish population dynamics, their ecological strategies, and stock origin (Brennan and Schindler, 2017; Kennedy et al., 2005; Kerr and Campana, 2013; Pracheil et al., 2014; Rojas et al., 2007; Thresher, 1999). These tools have also been used to control national and international fish trade (Pracheil et al., 2014) and to identify the geographical 
origin and conditions under which fishes have been raised (Barnett-Johnson et al., 2008; Bell et al., 2007; Rojas et al., 2007; Turchini et al., 2009). A sustainable community-based management is important to ensure secure and fair food production, thus valorizing the local economy, respecting the ecosystem functioning, and maintaining ecosystem services.

Determination of fish geographic origin by stable isotope analyses has been investigated by different authors aiming to characterize food origin, manage fisheries and fish stocks, build knowledge of species life history, identify critical habitats for conservation, and avoid overexploitation of fish stocks (Baffi and Trincherini, 2016; Duponchelle et al., 2016; Garcez et al., 2015; Hauser, 2018; Hegg et al., 2015; Jordaan et al., 2016; Pouilly et al., 2014; Pracheil et al., 2014). The methodological assumptions to discriminate fish stocks are based on (i) the isotopic heterogeneity among stocks and (ii) the low mobilization rates in the analyzed tissue (Kerr and Campana, 2013). Isotopic information can be extracted from calcified structures of fishes (scale, otolith, or vertebrae) in order to preserve fish integrity for commercial use and eventually reconstruct fish life history (Campana, 1999; Pouilly et al., 2014; Pracheil et al., 2014). Strontium isotopes have been used as an origin tracer of food products because of their robust response in terms of origin authenticity and fraud detection (Baffi and Trincherini, 2016). On the other hand, carbon isotopes have been used to distinguish farmed and wild fishes according to feeding patterns (Rojas et al., 2007; Turchini et al., 2009). Fish otoliths, or ear bones, are calcified structures that grow continually and record ambient conditions throughout a fish's life (Campana, 1999). Since $\mathrm{Sr}$ isotopes in otoliths are not reabsorbed and do not fractionate during biological uptake, the isotopic ratio of this element is a robust geographic marker (Kennedy et al., 2000; Kerr and Campana, 2013; Pouilly et al., 2014). Most studies using $\mathrm{Sr}$ isotopes in fish otoliths were performed on marine and freshwater ecosystems of temperate regions (Comyns, 2008; Gillanders, 2002; Kennedy et al., 1997, 2000, 2002; Woodhead et al., 2005). Only a few studies have focused on fish migration and living conditions in tropical river systems (Duponchelle et al., 2016; Garcez et al., 2015; Hauser, 2018; Hegg et al., 2015; Pouilly et al., 2014; Sousa et al., 2016; Walther et al., 2011).

The Amazon basin has the largest rainforest on the planet and constitutes a complex system of rivers, lakes, and wetlands (Oliveira, 1996). It has a variety of different river water types (white, black, or clear) that drains complex and heterogeneous geologic formations (Santos et al., 2015). Because these rivers drain rocks with different origins and ages, their waters present contrasting $\mathrm{Sr}$ isotopic compositions, thus providing an adequate scenario for the application of $\mathrm{Sr}$ isotopes as a geographic tracer (Duponchelle et al., 2016; Hauser, 2018; Pouilly et al., 2014; Santos et al., 2015). The region is also known to support a large diversity of fish species, many of which play an important economic role in the region, such as the Arapaima spp., known as one of the largest freshwater fish genus (Hrbek et al., 2007; Queiroz, 2000; Stone, 2007). The four described species (A. agassizii, A. mapae, A. leptosoma, and A. gigas) of this genus are endemic to the Amazon basin, where they are popularly called pirarucu or paiche (Arantes et al., 2010; Stewart, 2013a, b). This genus is socially, economically, and ecologically important in the region because it constitutes one of the main food sources for the local community, providing important economic resources on local and regional scales (farming, fishing, trading). Due to overexploitation, Arapaima spp. have been classified as vulnerable by CITES (Convention on International Trade in Endangered Species of Wild Fauna and Flora) and fishing is subject to legal restriction, such as seasonal fishing prohibition, minimum size of capture, and, most importantly, Arapaima's commercialization is restricted to fishes originated from management areas or aquaculture farms (Feio and Mendes, 2017). Paradoxically, Arapaima spp. are considered exotic invasive species in the upper Madeira watershed in Bolivia and Peru, after being introduced in the region in the 1970s (Van Damme et al., 2011; Figueiredo, 2013; Miranda-Chumacero et al., 2012).

Synergic actions initiated in 1989 and involving communitarian lake management, governmental conservation policies, non-governmental organization projects, and aquaculture production of Arapaima have allowed the recovery of overexploited stocks (Figueiredo, 2013; McGrath et al., 2015). For instance, more than 500 groups have permission for fishing Arapaima under an annual quota stipulated by the Brazilian Institute of Environment and Renewable Natural Resources (IBAMA), which have limited resources to monitor, control, and regulate fishery stocks (McGrath et al., 2015). Even though the "sustainable fishery" is certified with tags in order to allow traceability, these tags are easily counterfeited and illegally reused. In this context, the development of an isotopic tag to track back the origin of Arapaima fishery could reinforce the actual system of traceability and combat illegal exploitation of Arapaima stocks.

Some aspects of Arapaima spp. biology qualify this group as a model for isotopic certification. This genus is described as sedentary, although individuals migrate locally from lateral lakes to rivers during flooding pulses in order to complete their life cycle (Arantes et al., 2010; Araripe et al., 2013; Castello, 2008). Also, because this genus is air breath dependent, individuals come out of the surface to breath regularly and local fishermen can estimate population sizes and realize the certification of the communitarian management. These characteristics lead to a spatial distinction between stocks of the major Amazonian regions and allow us to use biogeochemical tags as a tracer of origin. Moreover, trophic patterns of Arapaima vary among populations and over the ontogeny from omnivorous (Watson et al., 2013) to carnivorous or piscivorous, predominantly based on $\mathrm{C}_{3}$ sources (Carvalho et al., 2018; Domingues et al., 2006; Queiroz, 2000). Because of this variation in feeding sources (Carvalho et al., 2018; Castello, 2008), a common strategy used in aqua- 
culture and strongly recommended by governmental manuals of Arapaima farming is the nutritional training with three rations during different life stages (Ono and Kehdi, 2013). As a reference, $\delta^{13} \mathrm{C}$ values of the food used on farming activity vary between $-19.3 \%$ and $-14.9 \%$, thus corresponding to a diet based mostly on $\mathrm{C}_{4}$ macrophytes, corn, and soya beans.

In this study, we hypothesize that farmed and wild fishes of different subbasins would present different $\delta^{13} \mathrm{C}$ and ${ }^{87} \mathrm{Sr} /{ }^{86} \mathrm{Sr}$ values, depending on their food sources $\left(\delta^{13} \mathrm{C}\right)$ and geographical origins $\left({ }^{87} \mathrm{Sr} /{ }^{86} \mathrm{Sr}\right)$. Hence, the main objective is to test whether $\delta^{13} \mathrm{C}$ and ${ }^{87} \mathrm{Sr} /{ }^{86} \mathrm{Sr}$ measured on fish otoliths can be used as biogeochemical tags of the geographic origin and provenance (wild vs. farmed) of Arapaima specimens and, consequently, evaluate if these isotopes can be used as a traceability tool. We analyzed $\mathrm{Sr}$ and $\mathrm{C}$ isotopic composition of Arapaima's otoliths from farmed and wild fishes proceeding from four different Amazonian regions (Madeira, Solimões, Central Amazon, Lower Amazon, Fig. 1). Sr and C isotope data were analyzed across a transect in Arapaima's otoliths in order to identify habitat change or geographic mobility during the fish lifetime. These data were also compared to the $\mathrm{C}$ and $\mathrm{Sr}$ isotopic composition of fish food supplied by the farmers.

\section{Material and methods}

\subsection{Study area}

The Amazon basin represents a dynamic and heterogeneous ecosystem extending over more than $45 \%$ of the surface area of South America. The Amazon River and its huge network of tributaries drain different geological formations (Gaillardet et al., 1997; Gibbs, 1967; Santos et al., 2015; Stallard, 1980; Stallard and Edmond, 1983) covered by primary forests, chaparral savannas, floodplains, and swamps. These habitats are therefore some of the most biodiverse in the world, particularly in regard to the Amazonian freshwater fish fauna, which are under ecological pressure from degradation by dams building, mining, changing land cover, and global climate change (Anderson et al., 2018; Carnicer et al., 2015; Castello et al., 2013; Castello and Macedo, 2016; Finer and Jenkins, 2012; Forsberg et al., 2017; Latrubesse et al., 2017; Lees et al., 2016; Winemiller et al., 2016).

The Amazon basin is a geomorphological depression located between two old and stable geological regions: the Guiana shield in the north and the Brazilian shield in the south. While the Andes mountain chain limits the western border of the basin, cratonic terrains and the Atlantic Ocean limit its eastern border. Owing to its complex geological history, rivers of the Amazon basin drain rocks with a wide range of $\mathrm{Sr}$ isotope compositions (Santos et al., 2015). For example, the Madeira and Negro rivers drain old rock formations, such as Precambrian and Ordovician rocks, that imprint a strong radiogenic $\mathrm{Sr}$ isotope signature in their waters (respectively $0.7168 \pm 0.0007$ and $0.7318 \pm 0.0074$; Santos et al., 2015). In contrast, the Solimões river drains younger formations as well as carbonate rocks, so that their water is characterized by less radiogenic $\mathrm{Sr}$ isotope ratios (0.7091 \pm 0.0002 ; Gaillardet et al., 1997; Santos et al., 2015). Because of this heterogeneity, $\mathrm{Sr}$ isotopes in the Amazon river waters may be used as a robust biogeographic marker for aquatic fauna (Duponchelle et al., 2016; Garcez et al., 2015; Hauser, 2018; Hegg et al., 2015; Pouilly et al., 2014; Sousa et al., 2016).

The carbon isotopic composition of an organism depends primarily on the isotopic composition of the primary producer that constitutes the basis of the trophic chain it feeds on. In particular, plants present with two main photosynthetic pathways, $\mathrm{C}_{3}$ and $\mathrm{C}_{4}$, of which the $\delta^{13} \mathrm{C}$ range of values are contrasting ( $-32 \%$ o to $-24 \%$ for $\mathrm{C}_{3}$ plants; $-14 \%$ o to $-9 \%$ for $\mathrm{C}_{4}$ plants; De Niro and Epstein, 1978). In general, wild Amazon fishes feed dominantly on a trophic chain derived from a $\mathrm{C}_{3}$ carbon source (Araujo-Lima et al., 1986; Forsberg et al., 1993; Jepsen and Winemiller, 2007; Marshall et al., 2008; Mortillaro et al., 2015; Watson et al., 2013).

\subsection{Fish otolith sampling}

Thirty-eight otolith samples of Arapaima spp. were collected in different sites of the four main regions (Fig. 1): 22 were obtained from professional fishermen for a commercial purpose, 6 were obtained from farmers, and 10 others were collected at Manaus and Santarém markets (Table 1). The sagitta otoliths of each specimen were extracted by head dissection after capture. Afterward, they were washed, dried, and kept until laboratory analyses. None of the fishes had precise location of capture, and the informed origin in four main regions were (Fig. 1): Solimões (Mamirauá reserve at the Solimões river), Madeira (Yata, Beni, and Madre de Dios rivers and Ariquemes farm), Central Amazon (Manacapuru farm, at Solimões river; Itacoatiara, at Amazon River; Novo Airão at Negro river) and Lower Amazon (Santarém, Amazon river). These regions have a complex drainage system that may include different sources of water with different $\mathrm{Sr}$ isotopic compositions in each site (Table 1). For example, Mamirauá reserve in Solimões region is located at the confluence of five major rivers, whose water types range from white (lower ${ }^{87} \mathrm{Sr} /{ }^{86} \mathrm{Sr}$ values) to black water (higher ${ }^{87} \mathrm{Sr} /{ }^{86} \mathrm{Sr}$ values). Similarly, Itacoatiara is located at the confluence zone of the Amazon and Madeira rivers, which also have quite distinct Sr isotopic compositions. Therefore, the lack of precise information of collection and the variability in regional water chemistry may not be exactly matched by literature data and may be important to explain the unexpected variance in fish otolith data. 


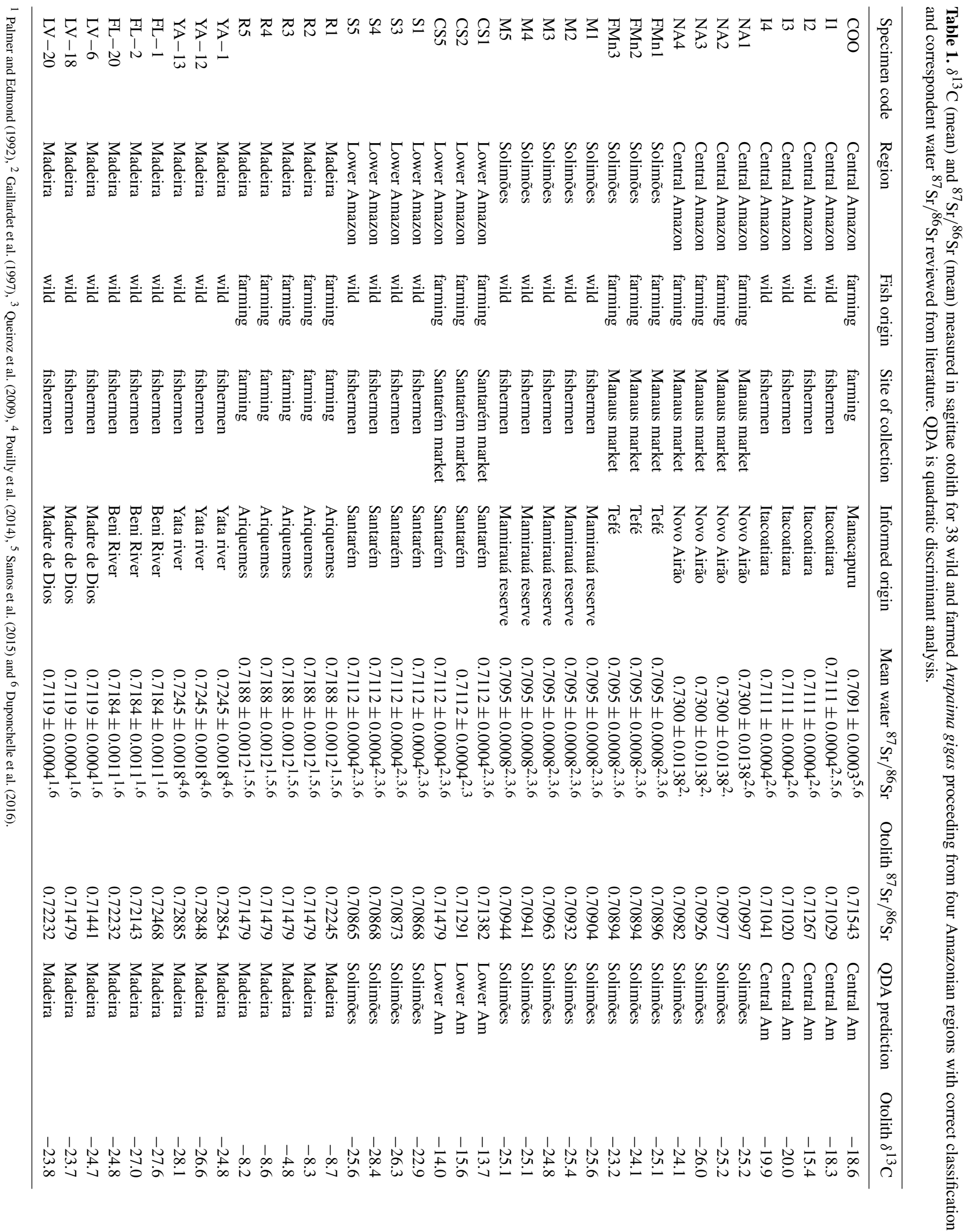




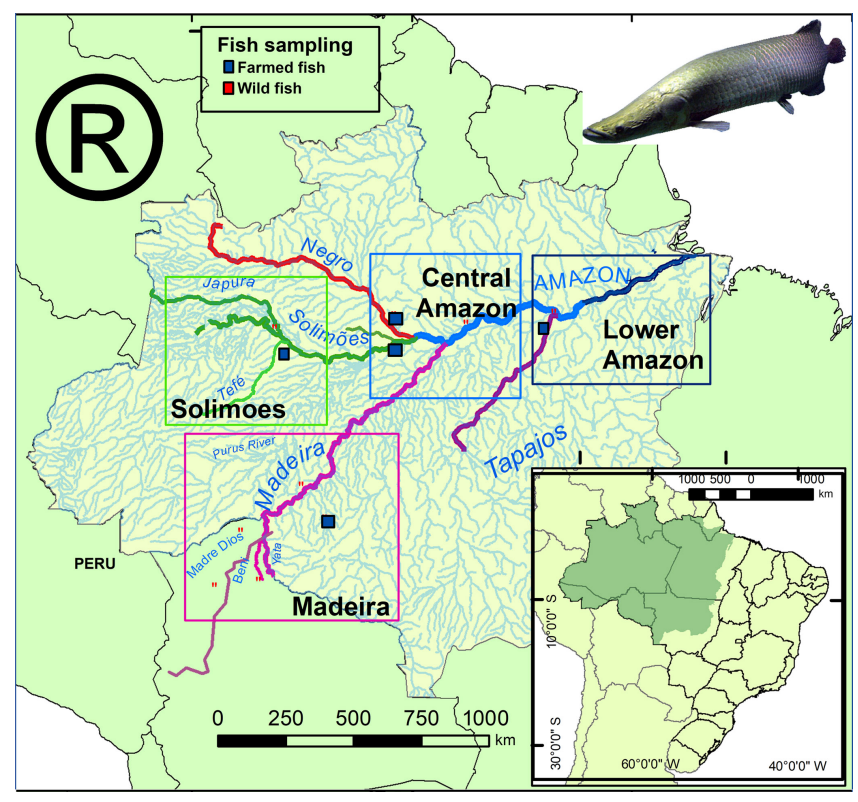

Figure 1. Map of the Amazon basin showing the regions and sampling sites for Arapaima spp. Wild collection sites are represented by red squares and farm collected sites by blue squares. The Amazon River (Lower Amazon and Central Amazon) is colored blue, the Solimões green, the Madeira purple, Tapajós purple, and the Negro red.

\subsection{Samples preparation and analytical methods}

The otoliths were sonicated in distilled water, dried, and mounted in Araldite epoxy resin at MARBEC laboratory in Montpellier University (France). Afterward, they were transversally cut with a low-speed saw (Isomed Buehler, Düsseldorf, Germany, 2009) to obtain a dorsoventral slice including the otolith core. The slices were then finely polished until the core could be seen, sonicated in distilled water, and mounted on glass using Crystalbond glue. Sr isotope analyses were performed at the Laboratoire de Chimie Analytique Bio-inorganique et Environnement (LCABIE) from the Institut Pluridisciplinaire de Recherche sur l'Environnement et les Matériaux (IPREM), Université de Pau et des Pays de l'Adour and in the laboratory PSO-IFREMER (Pole Spectrometrie Océan, Brest, France). Interlaboratory crosscalibration was performed to confirm the repeatability and comparability of the analysis (see Hauser, 2018, for details). The isotope ratios were measured using an La-fs-MCICPMS following the procedure detailed by (Claverie et al., 2009; Tabouret et al., 2010). Laser ablation conditions were $500 \mathrm{~Hz}$ and $20 \mu \mathrm{J}$ pulse energy until the depth limit of ablation $(<30 \mu \mathrm{m})$; the beam spot size was $10 \mu \mathrm{m}$ and its velocity was $5 \mu \mathrm{m} \mathrm{s}^{-1}$. The $\mathrm{Sr}$ isotope ratios were obtained by transects ( $200 \mu \mathrm{m}$ width; see Tabouret et al., 2010) along the major otolith axes, perpendicular to otolith growth lines. The laser-ablated material was carried with $\mathrm{He}$ gas to a double torch chamber in which the laser aerosol was mixed with a $2 \% \mathrm{HNO}_{3}$ solution before introduction into the plasma (Barats et al., 2007). These conditions were adjusted to obtain the maximal plasma sensibility and stability. Interferent ${ }^{87} \mathrm{Rb}$ signal was monitored by ${ }^{85} \mathrm{Rb}$, and ${ }^{87} \mathrm{Sr} /{ }^{86} \mathrm{Sr}$ was corrected following the procedure of Barnett-Johnson et al. (2010). Similarly, ${ }^{83} \mathrm{Kr}$ was measured to control ${ }^{84} \mathrm{Kr}$ and ${ }^{86} \mathrm{Kr}$ impact in ${ }^{84} \mathrm{Sr}$ and ${ }^{88} \mathrm{Sr}$ values, respectively. Finally, the ratio ${ }^{88} \mathrm{Sr} /{ }^{86} \mathrm{Sr}$ was used to correct ${ }^{87} \mathrm{Sr} /{ }^{88} \mathrm{Sr}$ and mass bias using the exponential law (Walther and Thorrold, 2008). Internal pattern ${ }^{87} \mathrm{Sr} /{ }^{86} \mathrm{Sr}$ ratio (NIESS 22 , certificated by the National Institute of Japan Environmental Studies) was analyzed at the beginning and end of each session of analysis to check the repeatability of the ${ }^{87} \mathrm{Sr} /{ }^{86} \mathrm{Sr}$ measurements.

Complete transects from core to edge were performed on 10 wild otolith samples, all of which presented a flat ${ }^{87} \mathrm{Sr} /{ }^{86} \mathrm{Sr}$ ratio pattern along the transect. For the remaining samples, the transect was performed only on the final onethird of the otoliths, which records the environmental condition during the last life period of the adult fish (Fig. 2). The results presented hereafter corresponds to the final part of the otolith for all individuals.

To obtain dietary information based on carbon isotopes, the same last one-third of each otolith was micro-drilled on the same slice preparations of otolith used to gather the $\mathrm{Sr}$ isotope data. The slice preparations were drilled with intervals of $6.8 \mathrm{~mm}$ using a "New Wave Microdrill" at the Universidade de Brasília. The drilled carbonate powder samples were placed directly into vials for isotope analysis. Carbon isotopes were measured using a Delta Plus V ThermoFisher mass spectrometer connected to a Finnigan GasBench II at the Laboratório de Isótopos Estáveis (LAIS), Instituto de Geociências Rede de Estudos Geocronológicos, Geodinâmicos e Ambientais (GEOCHRONOS), Universidade de Brasília, Brazil. The results were validated against reference standards NBS 18 and 19 (respectively $\delta^{13} \mathrm{C}=-5.0 \%$ and $1.9 \%$ ).

\subsection{Statistical analysis}

ANOVA was applied to test ${ }^{87} \mathrm{Sr} /{ }^{86} \mathrm{Sr}$ and the $\delta^{13} \mathrm{C}$ mean difference in otoliths among (1) wild fish proceeding from the four regions, and (2) farmed fishes from the four regions. A t test was also applied to evaluate the mean difference between all wild vs. farmed fishes. To evaluate the use of ${ }^{87} \mathrm{Sr} /{ }^{86} \mathrm{Sr}$ and $\delta^{13} \mathrm{C}$ as a predictive tracer of fish origin (farmed or wild) and subbasin/region of capture (Upper Amazon: Madeira and Solimões, Central Amazon, Lower Amazon), a quadratic discriminant analysis (QDA; Anderson et al., 2010; $\mathrm{Li}$ et al., 2016) was carried out using a crossvalidation by Jackknifed (leave one out) predictions procedure. All the statistical analyses were performed in R freeware (http://www.r-project.org/, last access: 10 April 2019). 


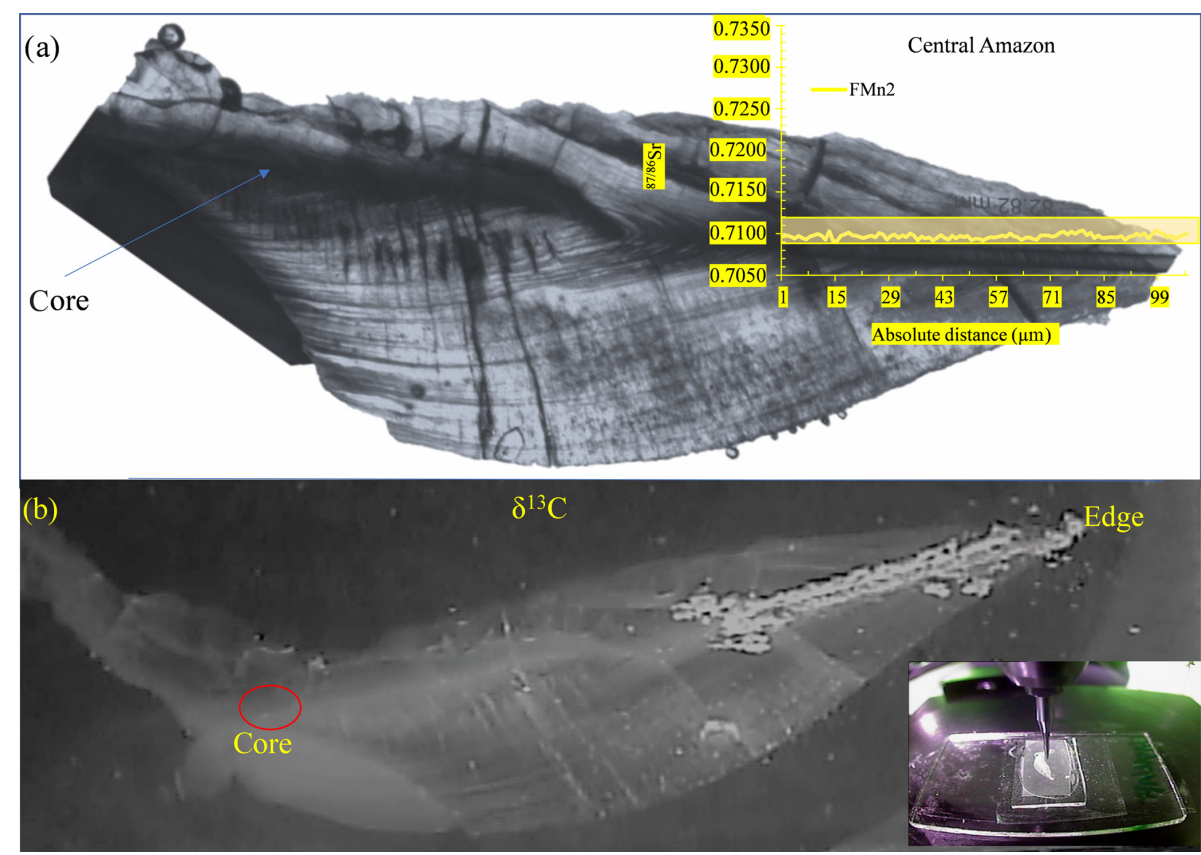

Figure 2. Photographs of an Arapaima's otolith slice preparation. (a) With the corresponding ${ }^{87} \mathrm{Sr} /{ }^{86} \mathrm{Sr}$ isotopic profile over the raster, which corresponds to the final part of a core to edge transect representing the last period of life of the individual before its capture, analyzed by laser ablation. The yellow rectangle illustrates the range of ${ }^{87} \mathrm{Sr} /{ }^{86} \mathrm{Sr}$ values of the Solimões waters in the Central Amazon and Lower Amazon. (b) Illustration of the microdrilling sampling performed in the same transect in order to analyze $\delta^{13} \mathrm{C}$ signatures.

\section{Results}

\subsection{Otolith $\mathrm{Sr}$ isotopic composition}

Significant differences were observed (Fig. 3) between (1) mean ${ }^{87} \mathrm{Sr} /{ }^{86} \mathrm{Sr}$ of wild fishes from the four sampled regions (ANOVA, $F=18.397, p<0.01$ ); (2) mean ${ }^{87} \mathrm{Sr} /{ }^{86} \mathrm{Sr}$ of farmed fishes from the four sampled regions (ANOVA, $F=5.614, p=0.0161$ ), and (3) mean ${ }^{87} \mathrm{Sr} /{ }^{86} \mathrm{Sr}$ of wild vs. farmed fishes of the same region $(t=-3.764, \mathrm{~d} f=31.805$, $p$ value $p<0,01$ ).

Except for two specimens, the wild fishes presented a narrow range of ${ }^{87} \mathrm{Sr} /{ }^{86} \mathrm{Sr}$ across the otoliths (Fig. 4) and their average ${ }^{87} \mathrm{Sr} /{ }^{86} \mathrm{Sr}$ values are comparable to ${ }^{87} \mathrm{Sr} /{ }^{86} \mathrm{Sr}$ of the river waters in which they were living (Table 1). The first exception is a fish from Central Amazon-Itacoatiara (I2) that exhibited ${ }^{87} \mathrm{Sr} /{ }^{86} \mathrm{Sr}$ similar to other individuals from the same site but also displayed a peak of ${ }^{87} \mathrm{Sr} /{ }^{86} \mathrm{Sr}$ value up to 0.7259 (Fig. 4a). The second exception is a specimen from the Solimões-Mamirauá area (M2) that presented higher ${ }^{87} \mathrm{Sr} /{ }^{86} \mathrm{Sr}$ values $(0.7223 \pm 0.0001)$ in comparison to the river values $(0.7090-0.7100)$ and to other individuals from the same site (0.709-0.7110, Fig. 4c).

The data also revealed differences in the variability in ${ }^{87} \mathrm{Sr} /{ }^{86} \mathrm{Sr}$ values among specimens from the same region (Fig. 3). Individuals from Solimões, Central Amazon (0.7090 to 0.7096), and Lower Amazon (0.7086 to 0.7087) presented

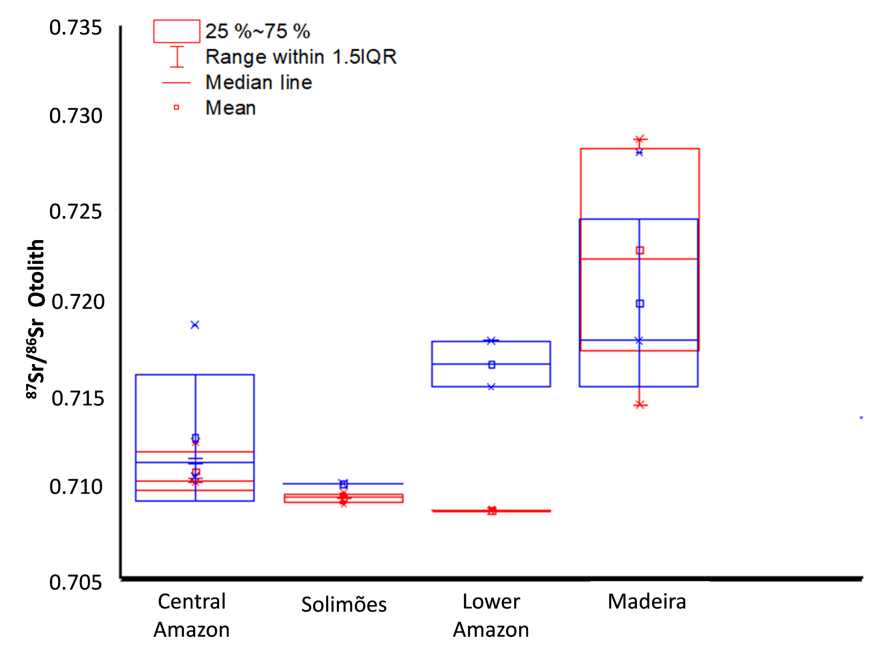

Figure 3. Box plot of otolith ${ }^{87} \mathrm{Sr} /{ }^{86} \mathrm{Sr}$ ratio of wild (red) and farmed (blue) Arapaima spp. from four Amazonian regions.

a low inter-individual variation in comparison to individuals from the upper Madeira (0.7144 to 0.7288) region.

A clear relationship also existed between the average ${ }^{87} \mathrm{Sr} /{ }^{86} \mathrm{Sr}$ values in otoliths of farmed fishes and in local river water. Farmed fishes also generally showed a flat profile of ${ }^{87} \mathrm{Sr} /{ }^{86} \mathrm{Sr}$ values along the otolith (Fig. 5), except for three individuals. One of the fishes collected directly with farmers at Manaus (COO) presented initial ${ }^{87} \mathrm{Sr} /{ }^{86} \mathrm{Sr}$ values similar 

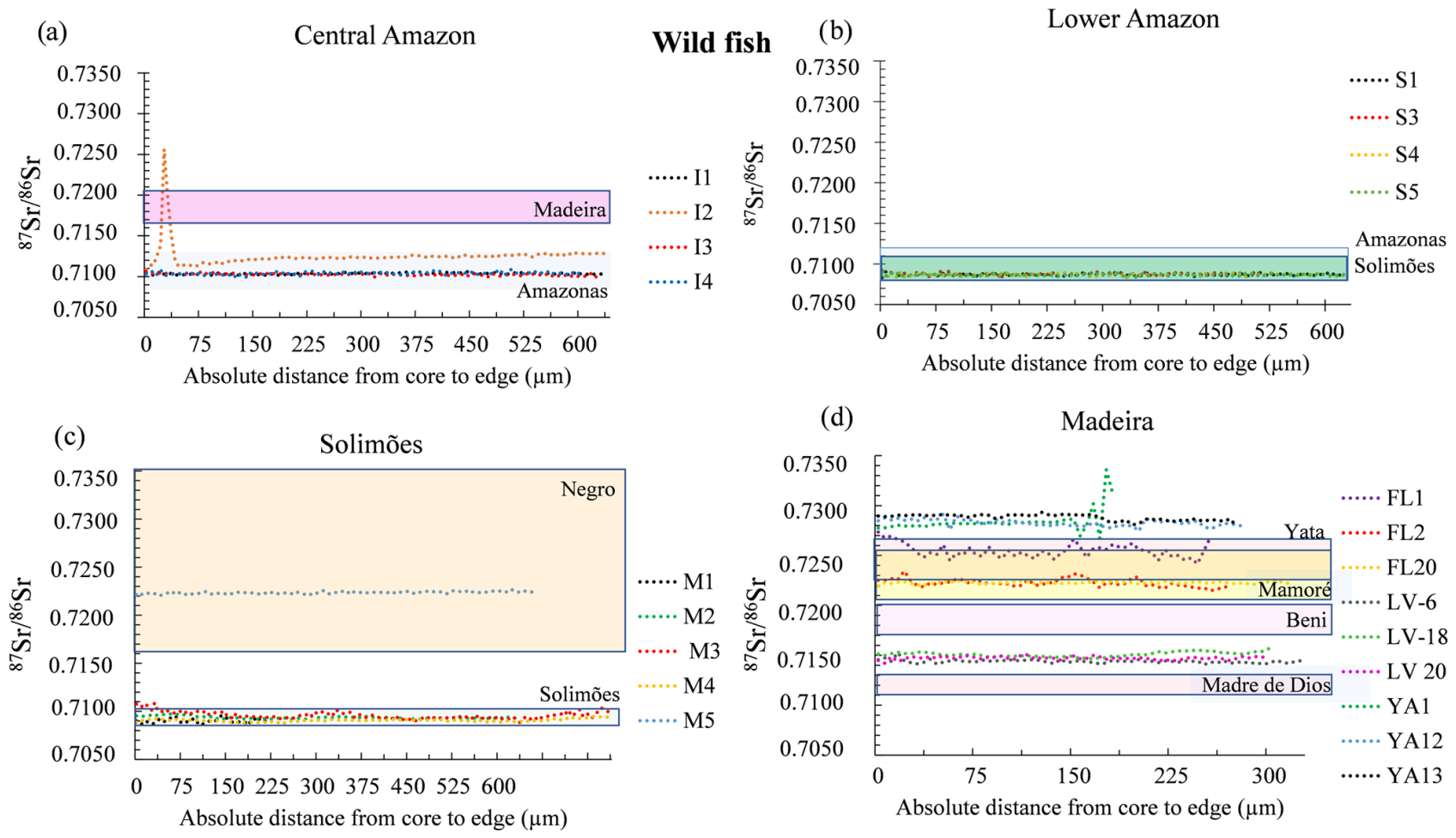

Figure 4. Variation of ${ }^{87} \mathrm{Sr} /{ }^{86} \mathrm{Sr}$ values measured by LAfs-MC-ICPMS (laser ablation femtosecond multi-collector inductively coupled plasma mass spectrometry) on wild fish otolith cores - edge transects. Only the final part of the transect (approximately one-third) is represented. Individual fishes were grouped by geographic region: (a) Central Amazon; (b) Madeira; (c) Lower Amazon, and (d) Solimões. The range of ${ }^{87} \mathrm{Sr} /{ }^{86} \mathrm{Sr}$ values of river water dissolved matter for each geographic region is indicated by a colored rectangle (based on literature and additional analyses, see Appendix Table A1).

to the Negro river waters. In contrast, ${ }^{87} \mathrm{Sr} /{ }^{86} \mathrm{Sr}$ values of the other specimens of the same region presented isotope ratios in the range of Solimões river waters during all their life (Fig. 5a). One specimen from the Lower Amazon - Santarém area (CS1) presented important fluctuations of ${ }^{87} \mathrm{Sr} /{ }^{86} \mathrm{Sr}$ values across the otolith, corresponding to values in the range of Tapajós river; although the two other specimens collected in the same area (CS2, CS3) presented flat profiles with values intermediate between the Amazon and Tapajós river waters (Fig. 5b). Finally, one of the farmed specimens of the Madeira River (R1) also showed a fluctuating ${ }^{87} \mathrm{Sr} /{ }^{86} \mathrm{Sr}$ profile (Fig. 5c), although the other four fishes showed a flat and completely overlapping profile.

\subsection{Food and otolith carbon isotopic composition}

The $\delta^{13} \mathrm{C}$ values of otoliths were significantly different among wild and farming specimens (ANOVA, $F=124.44$, $p<0.01$ ). Most samples of wild fish present $\delta^{13} \mathrm{C}$ consistent with $\mathrm{C}_{3}$ sources (mean $-28.9 \pm 1.2 \%$ ). The exceptions were all samples from Itacoatiara (Central Amazon), which display a mean $\delta^{13} \mathrm{C}$ value of $-18.4 \%$ o \pm 1.8 , that fall between the $\mathrm{C}_{3}$ and $\mathrm{C}_{4}$ signatures (Fig. 6). In contrast, otoliths of farmed fish presented a wide range of $\delta^{13} \mathrm{C}$ (mean
$-17.1 \% \circ \pm 7.7, \min =26.0 \%$ o, $\max =4.8 \%$ ). The otoliths of the fishes from the Madeira region farms presented a mean $\delta^{13} \mathrm{C}$ value of $-8.5 \% \circ \pm 0.1$, indicating a strong contribution of $\mathrm{C}_{4}$ plants in their feeding source. Farmed fish from the market of Santarém (Lower Amazon) presented a mean ${ }^{13} \mathrm{C}$ value of $-14.4 \% \circ \pm 0.8$ in their otoliths, thus revealing a contribution of both $\mathrm{C}_{3}$ and $\mathrm{C}_{4}$ plants in their feeding source. Otoliths of farmed fish from the market of Manaus (Central Amazon) presented a lower mean $\delta^{13} \mathrm{C}$ value $(-24.7 \% \circ \pm 0.8)$, indicating a main $\mathrm{C}_{3}$ feeding source.

\subsection{QDA discriminant analysis}

The ${ }^{87} \mathrm{Sr} /{ }^{86} \mathrm{Sr}$ and $\delta^{13} \mathrm{C}$ isotopes biplot shows that all otolith samples fall within four main groups (Fig. 6). The carbon isotopic composition combined with the average ${ }^{87} \mathrm{Sr} /{ }^{86} \mathrm{Sr}$ ratio of the fish otolith allows us to partially distinguish the different fish origins (farmed or wild) as well as their geographical region.

Wild fishes presented more negative $\delta^{13} \mathrm{C}$ values (mean $-24.3 \% \circ \pm 3.2$ ) corresponding to a diet more influenced by a $\mathrm{C}_{3}$ macrophyte carbon source, whereas farmed fishes presented less negative $\delta^{13} \mathrm{C}$ values (mean $-17.1 \%$ o 7.7 ), corresponding to a higher influence of $\mathrm{a}_{4}$ carbon source. How- 

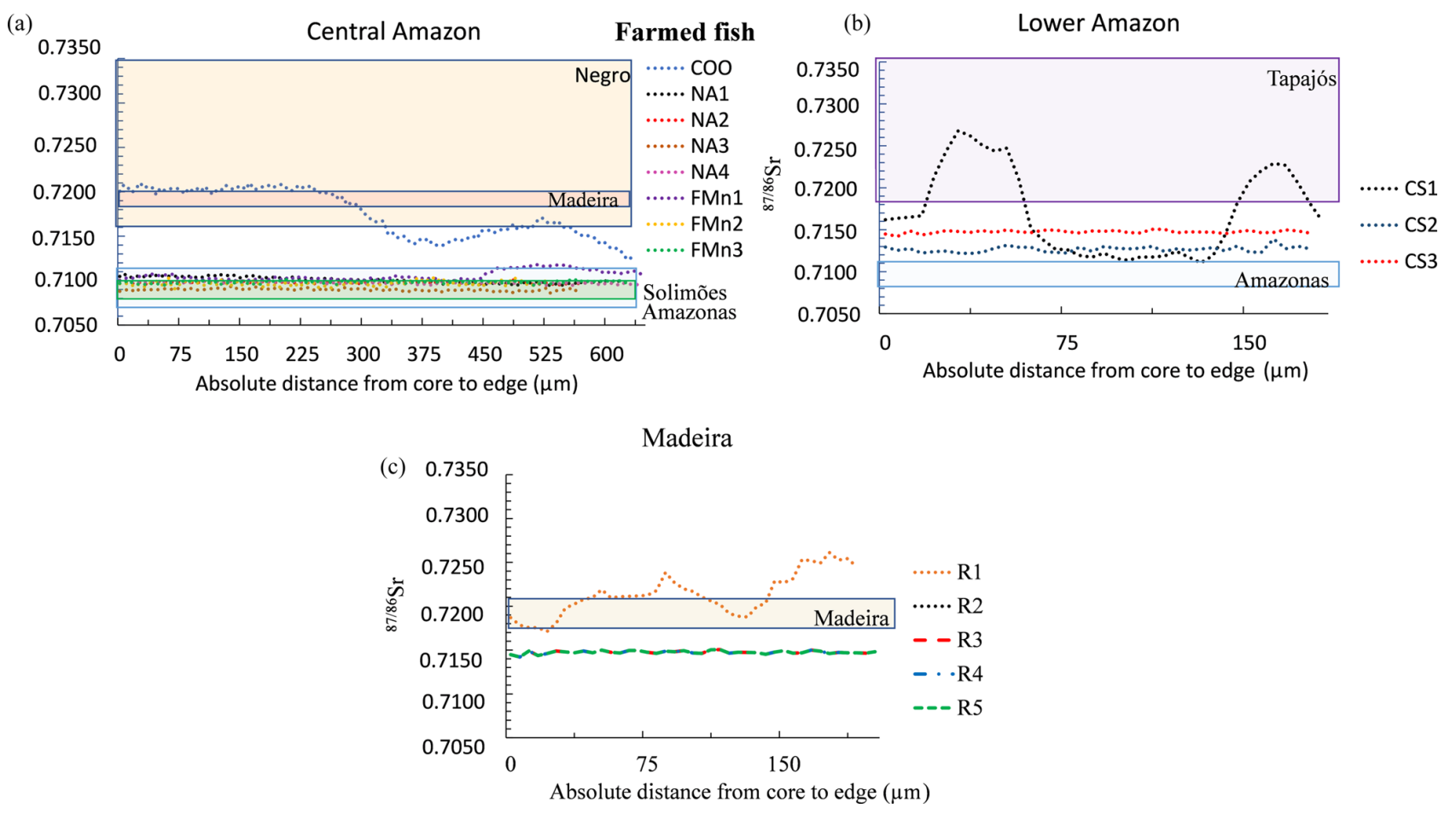

Figure 5. Variation of ${ }^{87} \mathrm{Sr} /{ }^{86} \mathrm{Sr}$ measured by LAfs-MC-ICPMS on farmed fish otolith cores - edge transects. Only the final part of the transect (approximately one-third) is represented. Individual fishes were grouped by geographic region: (a) Central Amazon (Manaus Market); (b) Lower Amazon (Santarém Market); (c) Madeira (Ariquemes farm). Note that individuals R2, R3, R4, and R5 present the same ${ }^{87} \mathrm{Sr} /{ }^{86} \mathrm{Sr}$ profile. The range of ${ }^{87} \mathrm{Sr} /{ }^{86} \mathrm{Sr}$ of river water dissolved matter for each geographic region is indicated by a colored rectangle (based on literature and additional analyses, see Appendix Table A1).

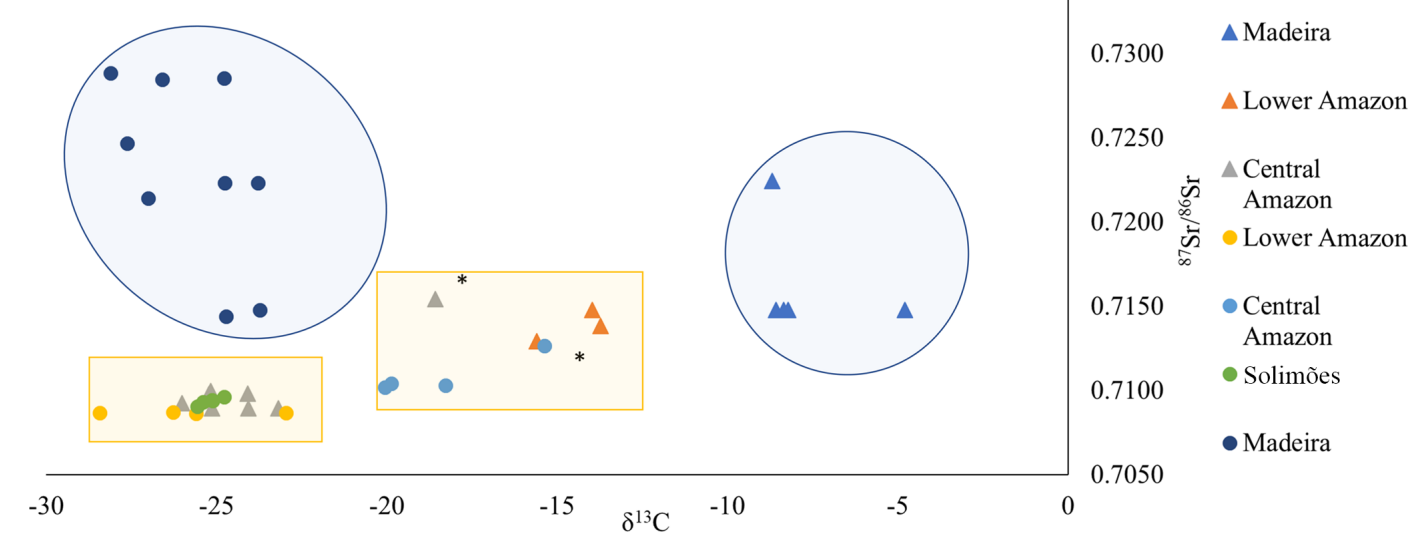

Figure 6. Biplot of mean $\delta^{13} \mathrm{C}$ and ${ }^{87} \mathrm{Sr} /{ }^{86} \mathrm{Sr}$ for 38 wild (circle symbols) and farmed (triangle symbols) Arapaima otoliths from four geographic regions. Large blue shading represent farmed and wild fish from the Madeira, and yellow squares wild and farmed fishes from Lower Amazon, Central Amazon, and Solimões. The only two samples that are out of their group are tagged with *.

ever, farmed fishes presented a higher variability indicating different sources of food depending on the farm. This variability led to low predictability of fish origin $(58 \%$ of correct classification, Table 2).

On the contrary, QDA analysis gave a higher score of correct classification of a fish's region ( $76 \%$, Table 3$)$. This per- centage varied between subbasins, from $100 \%$ (Madeira) to $29 \%$ (Lower Amazon). 
Table 2. Confusion matrix of fish origin classification by QDA (sample origin rows, predicted origin columns).

\begin{tabular}{lrrr}
\hline & Farm & Wild & $\begin{array}{r}\text { Correct } \\
\text { prediction }\end{array}$ \\
\hline Farm & 8 & 8 & 0.50 \\
Wild & 8 & 14 & 0.64 \\
\hline Total correct prediction & 0.58 \\
\hline
\end{tabular}

Table 3. Confusion matrix of fish region classification by QDA (sample origin rows, predicted origin columns). CA is the Central Amazon; LA is the Lower Amazon; MA is Madeira basin; SO is the Solimões basin.

\begin{tabular}{lrrrrr}
\hline & CA & LA & MA & SO & $\begin{array}{r}\text { Correct } \\
\text { prediction }\end{array}$ \\
\hline CA & 10 & 1 & 1 & 0 & 0.83 \\
LA & 4 & 2 & 1 & 0 & 0.29 \\
MA & 0 & 0 & 14 & 0 & 1.00 \\
SO & 2 & 0 & 0 & 3 & 0.60 \\
\hline \multicolumn{7}{l}{ Total correct prediction } \\
\hline
\end{tabular}

\section{Discussion}

The data presented show major differences in otolith's C and $\mathrm{Sr}$ isotopic composition among the studied populations of Arapaima. In general, the ${ }^{87} \mathrm{Sr} /{ }^{86} \mathrm{Sr}$ measured in otoliths of wild specimens were similar to the ${ }^{87} \mathrm{Sr} /{ }^{86} \mathrm{Sr}$ reported in the dissolved fraction of the river water in which they were caught. Furthermore, the pattern of variation of the ${ }^{87} \mathrm{Sr} /{ }^{86} \mathrm{Sr}$ ratio throughout the life of these individuals was mostly flat, indicating that studied Arapaima predominantly stayed in water with the same chemical composition (Araripe et al., 2013; Castello, 2004, 2008; Hermann et al., 2016; NúñezRodríguez et al., 2015; Queiroz, 2000; Viana et al., 2007). However, some variations were recorded and are related to the lack of precise information of the fishery site and the intricate mosaic of the Amazon water chemistry. They may either correspond to the seasonal variation of water composition, or to movements between the river and adjacent lagoons, which have been shown to have higher ${ }^{87} \mathrm{Sr} /{ }^{86} \mathrm{Sr}$ values than the river (Pouilly et al., 2014).

On the other hand, most farmed fishes also presented a flat profile, but some specimens presented abrupt variations in ${ }^{87} \mathrm{Sr} /{ }^{86} \mathrm{Sr}$ values along the otolith. These variations may be produced by changes in the water isotopic composition, due, for example, to a transfer of the fish to another pond, or to a modification of the water source filling the pond. However, the variation could also be a consequence of food change. Most strontium otolith studies indicated the role of ambient water in the control of strontium uptake. Controversially, the role of food in the strontium otolith uptake is debated, as revealed by Sturrock et al. (2012) that reviewed the significance of food up taking processes on the $\mathrm{Sr}$ isotopic composition of fish. For example, Kennedy et al. (2000) suggested that food consumption in adult hatchery-reared salmon is preponderant in the uptake of strontium, although Walther and Thorrold (2006) indicated that water chemistry is the dominant factor for marine fishes. Finally, recent advances highlighted that physiological factors may also contribute to $\mathrm{Sr}$ control in the otolith, because these elements are transferred into the blood plasma via branchial or intestinal uptake, before reaching the endolymph fluid, and finally the otolith (Payan et al., 2004; Sturrock et al., 2014). Although the importance of food in strontium uptake is not clear, we may speculate that in natural conditions strontium composition of fish and food sources are in equilibrium with river water, so that fish and water are directly correlated, with no significant relative contribution of food in the uptake. In artificial condition, however, strontium composition of exogenous food source could be different from water and may result in a gap between fish and water strontium composition corresponding to the relative importance of food in the uptake.

\subsection{Isotope record of wild Arapaima}

The relationship between $\mathrm{Sr}$ isotope ratios in water and fish otoliths or scales has revealed to be a robust tool to study fish migration and geographical origin of population in the Amazon basin (Duponchelle et al., 2016; Garcez et al., 2015; Hauser, 2018; Hegg et al., 2015; Pouilly et al., 2014; Sousa et al., 2016). The ${ }^{87} \mathrm{Sr} /{ }^{86} \mathrm{Sr}$ values of wild fishes from the Lower Amazon and Central Amazon and from the upper Madeira and Solimões rivers presented differences according to the regions (Figs. 3 and 4). Fishes from Lower Amazon and Central Amazon presented the narrowest variation in ${ }^{87} \mathrm{Sr} /{ }^{86} \mathrm{Sr}$ values during their life. These values were around 0.7100 , which agrees with the reported values for this river's waters (Santos et al., 2015). One fish presented a peak of the ${ }^{87} \mathrm{Sr} /{ }^{86} \mathrm{Sr}$ value of $>0.7250$ (Fig. 4a), which could correspond to a period during which this fish has lived in a habitat with water ${ }^{87} \mathrm{Sr} /{ }^{86} \mathrm{Sr}$ values close to the Madeira River waters or some granitic shield tributaries. Because of the sharpness of the peak, it could also be interpreted as an irregularity in the otolith. In contrast, fishes from the upper Madeira region, including the Beni, Mamoré, Yata, and Madre de Dios rivers, presented a higher degree of variability in ${ }^{87} \mathrm{Sr} /{ }^{86} \mathrm{Sr}$ values (Fig. $4 d$, from 0.7150 to 0.7350 ). Fishes from this region also presented a higher ${ }^{87} \mathrm{Sr} /{ }^{86} \mathrm{Sr}$ variation across each otolith profile when compared to fishes from other sites, which is consistent with the natural seasonal variation in these older geological regions. In the Madeira waters and its upper tributaries, Santos et al. (2015) observed dissolved ${ }^{87} \mathrm{Sr} /{ }^{86} \mathrm{Sr}$ data with a high seasonal variation, owing to the nature of rocks being eroded during the rainy and dry sea- 
sons. The data presented here suggest that fish otoliths also record these seasonal variations.

The wild fishes from the Solimões river were caught in the Mamirauá reserve. This reserve does not correspond to the main channel of the Solimões channel, but to lateral lakes that developed in a mixing zone with other tributaries, some of which may be of black waters that generally present ${ }^{87} \mathrm{Sr} /{ }^{86} \mathrm{Sr}$ similar to that reported for the Negro river (Santos et al., 2015). One of the five fishes analyzed presented higher ${ }^{87} \mathrm{Sr} /{ }^{86} \mathrm{Sr}$ values $(>0.720)$, suggesting it may have lived part of its life in such a black water tributary.

Besides this regional variation, the data presented revealed that in general individual fish lived in waters with a limited range of ${ }^{87} \mathrm{Sr} /{ }^{86} \mathrm{Sr}$ values, suggesting a resident behavior. The pattern of ${ }^{87} \mathrm{Sr} /{ }^{86} \mathrm{Sr}$ along the otolith from the Madeira fishes presented higher variations. This could either result from movements between habitats with contrasted ${ }^{87} \mathrm{Sr} /{ }^{86} \mathrm{Sr}$ water signatures (e.g., adjacent lakes and lagoon, as shown by Pouilly et al., 2014, for the Beni River) or from the integration of the important natural seasonal variations in ${ }^{87} \mathrm{Sr} /{ }^{86} \mathrm{Sr}$ signature in the Madeira waters described by Santos et al. (2015).

Previous studies also concluded a resident behavior of Arapaima species (Araripe et al., 2013; Castello, 2004, 2008; Hermann et al., 2016; Queiroz, 2000; Viana et al., 2007), including a study of individual behavior of restocked and wild Arapaima using radio telemetry (Núñez-Rodríguez et al., 2015). A flat ${ }^{87} \mathrm{Sr} /{ }^{86} \mathrm{Sr}$ profile along the otolith does not directly implicate an absence of movement. Indeed, if a fish moves across two habitats presenting the same isotopic signature, the movement would not be revealed by otolith microchemistry analyses. On the other hand, Castello (2008) demonstrated lateral migration of pirarucu between the Solimões river and the floodplain during water pulse in the Mamirauá reserve with other observation methods. Based on our results, we can conclude that studied Arapaima did not show movements across contrasted habitats (for example white vs. black water systems; Santos et al., 2015). We cannot, however, exclude lateral movements across habitats with similar water signatures. We argue that the ${ }^{87} \mathrm{Sr} /{ }^{86} \mathrm{Sr}$ variations observed in each otolith can be a combination of (1) small changes in the isotopic composition of water due to diverse tributary sources in the hydrological seasonal cycle and/or (2) a lateral migration. As an example, the M3 fish from the Mamirauá showed ripples that might be interpreted as lateral movements between the Solimões white waters and adjacent lagoons or lakes with a slightly higher signature (see Pouilly et al., 2014). Due to the weakness of the pattern and the absence of ${ }^{87} \mathrm{Sr} /{ }^{86} \mathrm{Sr}$ seasonal data from lakes and rivers in the Amazon basin, more detailed studies would be necessary to confirm one or the other hypothesis of movement behavior, which are probably complementary.

Strontium and carbon isotopes in fish otolith record different parameters during a specimen's life. As ${ }^{87} \mathrm{Sr} /{ }^{86} \mathrm{Sr}$ values could be used as a robust fish geographical indicator, even in small scales (Pouilly et al., 2014), carbon isotope compositions $\left(\delta^{13} \mathrm{C}\right)$ are related to the feeding source of the fishes.

Most wild fishes analyzed presented $\delta^{13} \mathrm{C}$ values between $-24 \%$ and $-30 \%$ (Fig. 6). Hence, wild Arapaima in this study had $\delta^{13} \mathrm{C}$ mostly derived from $\mathrm{C}_{3}$ plants $(-28.9 \pm$ $1.2 \%$ ), as also observed in previous studies (Domingues et al., 2006; Forsberg et al., 1993; Watson et al., 2013). However, a higher contribution of $\mathrm{C}_{4}$ plants could be observed in some specimens; in particular, fishes from the Central Amazon region (Itacoatiara site) that presented more positive $\delta^{13} \mathrm{C}$ values $(-15.4 \%$ and $-20.1 \%$ ). Forsberg et al. (1993) showed that $\mathrm{C}_{3}$ may account for $82.4 \%$ to $97.5 \%$ of the fish diet in the Amazon basin. Nonetheless, it is worth mentioning that these studies analyzed muscle tissue and there may exist isotopic differences between carbon in muscle tissue and in bone structures because of physiological pathway incorporation. Although this fractionation is not known in Amazonian fishes, available data from Atlantic cod indicate that $\delta^{13} \mathrm{C}$ values can be $15.9 \%$ higher in otoliths than in body tissues (Radtke et al., 1996). If this same fractionation were applied to the otoliths of Arapaima, the carbon source would have an unlikely value of $-44.8 \%$. This fractionation difference is likely lower for Amazonian fishes as also suggested by the carbon isotopic composition of other calcified tissues, such as scales reported by Domingues et al. (2006). They showed that these calcified tissues have $\delta^{13} \mathrm{C}$ values between $-18.0 \%$ and $-29.2 \%$, which are in the same range as samples from the present study. The more positive $\delta^{13} \mathrm{C}$ values observed in fishes from Itacoatiara in the Central Amazon may reflect environmental heterogeneity related to water types (white, black, and clear), channel formations in the dry season, and other hydrologic seasonality related to the flood pulse concept (Domingues et al., 2006; Junk et al., 1989; Oliveira et al., 2006). Moreover, these isotopic values may be related to seasonal resource availability, such as Schizodon fasciatus that presents major digestibility of $\mathrm{C}_{4}$ macrophytes in the várzea areas (Forsberg et al., 1993; Mortillaro et al., 2015; Oliveira et al., 2006).

\subsection{Isotopic variations in farmed fish otoliths}

In general, farmed fishes also presented a flat ${ }^{87} \mathrm{Sr} /{ }^{86} \mathrm{Sr}$ profile, except for three fishes (CS1, FMn2, and R1) that showed a larger ${ }^{87} \mathrm{Sr} /{ }^{86} \mathrm{Sr}$ profile variation when compared to wild fishes from the same region (Fig. 5). These variations could be related to the physical conditions of the water pond in which they have been raised and/or to abrupt changes in water type, such as seasonal pond transfer. We argue that these fishes were probably used as breeders and that the changes in $\mathrm{Sr}$ isotope ratio indicate that they were transferred between different ponds with different $\mathrm{Sr}$ isotope compositions. Indeed, fish farming manuals indicate that changing the breeders from one pond to another is an important strategy to increase reproduction (Ono and Kehdi, 2013; SEBRAE, 2010). On the other hand, four fishes (R2, R3, R4, and R5) of the 
Madeira farm had the exact same $\mathrm{Sr}$ isotopic profile, suggesting they have lived the last part of their lives in the same common pond.

Compared to wild fish, farmed fish also showed a higher variation in $\delta^{13} \mathrm{C}$, thus indicating more diversified food sources. Fishes from the Madeira (Ariquemes farm) presented less negative $\delta^{13} \mathrm{C}$ values (from $-8.7 \%$ o to $-4.8 \%$ ), which could be related to $\mathrm{C}_{4}$-based food (DeNiro and Epstein, 1978; Sant'Ana et al., 2010), probably containing a large proportion of corn. Farmed fishes from the Lower Amazon (Santarém farms) presented intermediate values (from $-15.6 \%$ to $-13.7 \%$ ) and those from the central Amazon (Manaus farms) had more negative values (from $-26.0 \%$ to $-23.2 \%$ ) more related to $\mathrm{C}_{3}$-based food. Therefore, we conclude that our hypothesis of an artificial alimentation based on $\mathrm{C}_{4}$ plants is not always verified, and that food farming seems to depend from local or regional production or from feeding strategies used by the farm.

\subsection{Combining ${ }^{87} \mathrm{Sr} /{ }^{86} \mathrm{Sr}$ and $\delta^{13} \mathrm{C}$ signatures}

We aimed at verifying if the combination of $\mathrm{Sr}$ and $\mathrm{C}$ isotopes may be a powerful tool to distinguish between farmed and wild specimens from different Amazonian regions. The quality of information concerning fish origin is an important parameter for sustainable fish commercialization. The lack of a precise fishing site and the heterogeneity of the water system may bring uncertainties to the data but does not compromise the scope of this study and our conclusions. This is also a sensitive question when considering that commercialization of Arapaima is only allowed from farming or management areas. In this sense, the isotope tool applied in this study can be improved to better control commerce in the actual system of traceability tracking back the origin of fish and combat the illegal reuse of tags on illicit fisheries.

The QDA presented in this study gives the proportion of correct prediction of the origin of fishes (production method: farm or wild, geographic regions). The results showed a good but not sufficient enough (>75\%) percentage of correct classification of the geographic origin (mainly based on ${ }^{87} \mathrm{Sr} /{ }^{86} \mathrm{Sr}$ values). This percentage is downgraded by the overlaps of ${ }^{87} \mathrm{Sr} /{ }^{86} \mathrm{Sr}$ values of some regions (Solimões, Central Amazon, and Lower Amazon). The lack of contrast in ${ }^{87} \mathrm{Sr} /{ }^{86} \mathrm{Sr}$ values between Lower Amazon, Central Amazon, and Solimões regions leads to a higher confusion: four fishes from the Lower Amazon (of a total of seven) and two fishes from Solimões (of a total of five) were misclassified in the Central Amazon region, most of them prevenient from farmed sources. On the contrary, it is upgraded by some clear contrasts existing in different Amazonian subbasins, such as the Madeira, but we can also indicate the Tapajós or Negro rivers that also presented specific values (Santos et al., 2015; review in Hauser, 2018).

On the one hand, results showed low predictability (58\%) of fish origin (farmed or wild). This is mainly due to the va- riety of food sources used to feed the farmed fishes. We hypothesized that farms used food based on a mixture of $\mathrm{C}_{3}$ and $\mathrm{C}_{4}$ plants (soya bean, corn) but some farms apparently used food based on $\mathrm{C}_{3}$ plants, generating confusion with the food of wild fishes. On the other hand, all fishes sold in Manaus marked as farmed fishes presented $\mathrm{C}_{3}$-based $\delta^{13} \mathrm{C}$ signatures. This could mean that these supposedly farmed fish actually came from wild provenance, which is illegal and contributes to the over exploration of this natural resource. False information on the fish provenance would also hamper the precision of our approach.

As a preliminary intent, the method gave some interesting results that emphasize the potential of such analyses to obtain a well performing tool. In only a few cases, the ${ }^{87} \mathrm{Sr} /{ }^{86} \mathrm{Sr}$ values recorded in wild fish otoliths were not in agreement with the ${ }^{87} \mathrm{Sr} /{ }^{86} \mathrm{Sr}$ water of the reported origin. For instance, the ${ }^{87} \mathrm{Sr} /{ }^{86} \mathrm{Sr}$ values of wild Arapaima obtained from Santarém market, Lower Amazon, were similar to those observed in the Solimões river (CS3). Hence, it is possible that these wild specimens were caught in the Solimões river (e.g., Mamirauá reserve) and not in the Santarém area as reported by the fish seller. Nonetheless, because of the scarcity of ${ }^{87} \mathrm{Sr} /{ }^{86} \mathrm{Sr}$ water baseline in this area, a Santarém origin cannot be completely ruled out. Some farmed fishes may also have ${ }^{87} \mathrm{Sr} /{ }^{86} \mathrm{Sr}$ values that are not in agreement with the expected values of the reported origin. For example, farmed fishes from the Lower Amazon (Santarém) were probably raised in a pond filled with water from both the Amazon and Tapajós river. Thus, the farming conditions are likely to interfere with the two tracers used in this study.

\section{Conclusions}

The expected differences in $\delta^{13} \mathrm{C}$ between farmed and wild fishes (related to artificial vs. natural food sources) could not be confirmed, owing mainly to the $\mathrm{C}_{4}$ macrophyte contribution to the natural alimentation of wild fishes and to the use of $\mathrm{C}_{3}$-based food sources for farmed fishes. False information on the fish provenance in markets may also have contributed to decreasing the precision of the approach and market sampling should be avoided in future studies. Another weakness of our approach is in the ${ }^{87} \mathrm{Sr} /{ }^{86} \mathrm{Sr}$ data overlapping among Amazon subbasins and the lack of a more extensive ${ }^{87} \mathrm{Sr} /{ }^{86} \mathrm{Sr}$ water baseline. Hence, this preliminary result is not yet fully sufficient to be applied as a commercial traceability tool and further analyses are needed to increase the discrimination performance because millions of people rely on Arapaima spp. for subsistence and income. Nonetheless, these initial results encourage a more detailed seasonal ${ }^{87} \mathrm{Sr} /{ }^{86} \mathrm{Sr}$ water sampling in lakes and rivers in all four regions analyzed, and especially in the Madeira and in the Mamirauá reserve, in order to refine the spatial water base and consequently to understand the causes of the otolith profile variation in wild Arapaima spp. Results also suggest fur- 
ther aspects of the investigation, such as controlled physiological experiment to clarify the sources (water and food) for ${ }^{87} \mathrm{Sr} /{ }^{86} \mathrm{Sr}$ otolith assimilation pathways in farmed conditions and investigating the actual importance of $\mathrm{C}_{4}$ macrophyte influence to both farmed and wild Arapaima according to season.

Data availability. Isotopic data are available at https://doi.org/10.5281/zenodo.2646436 (Pereira et al., 2019). Data includes (1) mean carbon isotopic signature and mean $\mathrm{Sr}$ isotopic ratio ${ }^{87} \mathrm{Sr} /{ }^{86} \mathrm{Sr}$ of Arapaima spp. (see Table 1 of the paper); (2) water ${ }^{87} \mathrm{Sr} /{ }^{86} \mathrm{Sr}$ (see Table $\mathrm{S} 1$ in the Supplement); (3) wild fish $\mathrm{Sr}$ profile: data used to draw Fig. 5 (Variation of ${ }^{87} \mathrm{Sr} /{ }^{86} \mathrm{Sr}$ values measured by LAfs-MC-ICPMS on wild fish otolith cores - edge transects); and (4) Farmed fish $\mathrm{Sr}$ profile: data used to draw Fig. 6 (Variation of ${ }^{87} \mathrm{Sr} /{ }^{86} \mathrm{Sr}$ measured by LAfs-MC-ICPMS on farmed fish otolith cores - edge transects). ${ }^{87} \mathrm{Sr} /{ }^{86} \mathrm{Sr}$ profile data correspond to the last $30 \%$ of each otolith transects. For some fishes tagged with *, less than the entire column was used in the graphic of Figs. 5 and 6. 


\section{Appendix A}

Table A1. Mean \pm SD dissolved ${ }^{87} \mathrm{Sr} /{ }^{86} \mathrm{Sr}$ for 18 amazonian sites.

\begin{tabular}{|c|c|c|c|}
\hline Local sampling & Latitude & Longitude & ${ }^{87} \mathrm{Sr} /{ }^{86} \mathrm{Sr}$ \\
\hline Manacapuru & $3^{\circ} 18^{\prime} 23.0^{\prime \prime} \mathrm{S}$ & $60^{\circ} 37^{\prime} 54.8^{\prime \prime} \mathrm{W}$ & $0.7091 \pm 0.0001$ \\
\hline Itacoatiara & $2^{\circ} 48.115^{\prime} \mathrm{S}$ & $57^{\circ} 56.085^{\prime} \mathrm{W}$ & $0.71018 \pm 0.0001$ \\
\hline Novo Airão & $2^{\circ} 39.688^{\prime} \mathrm{S}$ & $60^{\circ} 53.032^{\prime} \mathrm{W}$ & $0.7091 \pm 0.0001$ \\
\hline Mamirauá & $2^{\circ} 58.164^{\prime} \mathrm{S}$ & $64^{\circ} 53.911^{\prime} \mathrm{W}$ & $0.7104 \pm 0.0001$ \\
\hline Tefé lake/Solimões/Mamirauá & $3^{\circ} 20.815^{\prime} \mathrm{S}$ & $64^{\circ} 42.826^{\prime} \mathrm{W}$ & $0.71053 \pm 0.0001$ \\
\hline Tucuxi lake/Japurá/Mamirauá & $2^{\circ} 49.491^{\prime} \mathrm{S}$ & $65^{\circ} 00.818^{\prime} \mathrm{W}$ & $0.70860 \pm 0.0001$ \\
\hline Japurá/Mamirauá & $2^{\circ} 52.614^{\prime} \mathrm{S}$ & $64^{\circ} 55184^{\prime} \mathrm{W}$ & $0.70874 \pm 0.0001$ \\
\hline Japurá mix with Aranapu/Mamirauá & $2^{\circ} 14.897^{\prime} \mathrm{S}$ & $65^{\circ} 11.149^{\prime} \mathrm{W}$ & $0.70993 \pm 0.0002$ \\
\hline Aranapu/Mamirauá & $2^{\circ} 22.730^{\prime} \mathrm{S}$ & $65^{\circ} 15.426^{\prime} \mathrm{W}$ & $0.70857 \pm 0.0001$ \\
\hline Solimões/Mamirauá & $2^{\circ} 14.897^{\prime} \mathrm{S}$ & $65^{\circ} 11.147^{\prime} \mathrm{W}$ & $0.70858 \pm 0.0001$ \\
\hline Arapaima lake/Solimões & $2^{\circ} 59.016^{\prime} \mathrm{S}$ & $64^{\circ} 55.193^{\prime} \mathrm{W}$ & $0.7088 \pm 0.0002$ \\
\hline Santarém & $2^{\circ} 24.212^{\prime} \mathrm{S}$ & $54^{\circ} 44.149^{\prime} \mathrm{W}$ & $0.71114 \pm 0.0001$ \\
\hline Santarém & $2^{\circ} 23.663^{\prime} \mathrm{S}$ & $54^{\circ} 43.468^{\prime} \mathrm{W}$ & $0.71073 \pm 0.0001$ \\
\hline Porto Velho & $8^{\circ} 42.619^{\prime} \mathrm{S}$ & $63^{\circ} 55.425^{\prime} \mathrm{W}$ & $0.7168 \pm 0.0001$ \\
\hline Ariquemes & $9^{\circ} 53.682^{\prime} \mathrm{S}$ & $63^{\circ} 3.977^{\prime} \mathrm{W}$ & $0.72961 \pm 0.0001$ \\
\hline Beni & $11^{\circ} 01.276^{\prime} \mathrm{S}$ & $66^{\circ} 06.462^{\prime} \mathrm{W}$ & $0.71903 \pm 0.0001$ \\
\hline Beni + Madre Dios & $10^{\circ} 59.191^{\prime} \mathrm{S}$ & $66^{\circ} 03.440^{\prime} \mathrm{W}$ & $0.71310 \pm 0.0001$ \\
\hline Mamoré & $14^{\circ} 52.982^{\prime} \mathrm{S}$ & $65^{\circ} 01.963^{\prime} \mathrm{W}$ & $0.72135 \pm 0.0001$ \\
\hline
\end{tabular}


Author contributions. In this work, MP and RVS designed the overall project ideas; RVS and LAP developed the sampling plan. For the project execution, LAP collected samples from the Central Amazon and Lower Amazon and FC and $\mathrm{MH}$ sampled in Bolivia and Madeira. Then, the sample preparation, $\delta^{13} \mathrm{C}$ otolith analysis, and ${ }^{87} \mathrm{Sr} /{ }^{86} \mathrm{Sr}$ water analysis were made by LAP with the supervision of RVS, while the ${ }^{87} \mathrm{Sr} /{ }^{86} \mathrm{Sr}$ otolith analysis was performed by $\mathrm{MH}, \mathrm{CP}$, and SB with the supervision of MP and FDL. MP and LAP performed statistical and data analysis. Finally, LAP prepared the manuscript with the contributions from all co-authors.

Competing interests. The authors declare that they have no conflict of interest.

Acknowledgements. This manuscript is the result of the masters degree of Luciana Alves Pereira in the Graduate Program in Ecology at the University of Brasília. The authors would like to thank CNPq (Conselho Nacional de Desenvolvimento Científico e tecnológico) for the financial support to RVS (310641/2014-4 and 428843/2016-6); the University of Brasília for the financial publication support; the Laboratory of Ichthyology and Fishery at Universidade Federal de Rondônia, Porto Velho; the Mamirauá Institute for the logistical support on field sampling; the IRD (Institute pour Recherche et Development); the Université de Pau et des Pays de l'Adour/CNRS,LIABLE-IPREM, Pau, France; the Geochronology and Isotope Geochemistry Laboratory of University of Brasília; and Wikus Jordan and an anonymous referee for the review and input to this paper.

Review statement. This paper was edited by Steven Bouillon and reviewed by Wikus Jordaan and one anonymous referee.

\section{References}

Anderson, E. P., Jenkins, C. N., Heilpern, S., Maldonado-Ocampo, J. A., Carvajal-Vallejos, F. M., Encalada, A. C., Rivadeneira, J. F., Hidalgo, M., Cañas, C. M., Ortega, H., Salcedo, N., Maldonado, M., and Tedesco, P. A.: Fragmentation of Andes-toAmazon connectivity by hydropower dams, Sci. Adv., 4, 1642, https://doi.org/10.1126/sciadv.aao1642, 2018.

Anderson, K. A., Hobbie, K. A., and Smith, B. W.: Chemical profiling with modeling differentiates wild and farmraised salmon, J. Agr. Food Chem., 58, 11768-11774, https://doi.org/10.1021/jf102046b, 2010.

Arantes, C. C., Castello, L., Stewart, D. J., Cetra, M., and Queiroz, H. L.: Population density, growth and reproduction of arapaima in an Amazonian river-floodplain, Ecol. Freshw. Fish, 19, 455465, https://doi.org/10.1111/j.1600-0633.2010.00431.x, 2010.

Araripe, J., Rêgo, P. S. do, Queiroz, H., Sampaio, I., and Schneider, H.: Dispersal Capacity and Genetic Structure of Arapaima gigas on Different Geographic Scales Using Microsatellite Markers, PLoS One, 8, e54470, https://doi.org/10.1371/journal.pone.0054470, 2013.

Araujo-Lima, C. A. R. M., Forsberg, B. R., Victoria, R., and Martinelli, L.: Energy sources for detritivo- rous fish in the Amazon, Science, 234, 1256-1258, https://doi.org/10.1126/science.234.4781.1256, 1986.

Baffi, C. and Trincherini, P R: Food traceability using the ${ }^{87} \mathrm{Sr} /{ }^{86} \mathrm{Sr}$ isotopic ratio mass spectrometry, Eur. Food Res. Technol., 242, 1411-1439, https://doi.org/10.1007/s00217-016-2712-2, 2016.

Barats, A., Pécheyran, C., Amouroux, D., Dubascoux, S., Chauvaud, L., and Donard, O. F. X.: Matrix-matched quantitative analysis of trace-elements in calcium carbonate shells by laserablation ICP-MS: application to the determination of daily scale profiles in scallop shell (Pecten maximus), Anal. Bioanal. Chem., 387, 1131-1140, https://doi.org/10.1007/s00216-0060954-8, 2007.

Barnett-Johnson, R., Pearson, T. E., Ramos, F. C., Grimes, C. B., and MacFarlane, R. B.: Tracking natal origins of salmon using isotopes, otoliths, and landscape geology, Limnol. Oceanogr., 53, 1633-1642, https://doi.org/10.4319/lo.2008.53.4.1633, 2008.

Barnett-Johnson, R., Teel, D. J., and Casillas, E.: Genetic and otolith isotopic markers identify salmon populations in the Columbia River at broad and fine geographic scales, Environ. Biol. Fish., 89, 533-546, https://doi.org/10.1007/s10641-010-9662-5, 2010.

Bell, J. G., Preston, T., Henderson, R. J., Strachan, F., Bron, J. E., Cooper, K., and Morrison, D. J.: Discrimination of wild and cultured European sea bass (Dicentrarchus labrax) using chemical and isotopic analyses, J. Agr. Food Chem., 55, 5934-5941, https://doi.org/10.1021/jf0704561, 2007.

Brennan, S. R. and Schindler, D. E.: Linking otolith microchemistry and dendritic isoscapes to map heterogeneous production of fish across river basins, Ecol. Appl., 27, 363-377, https://doi.org/10.1002/eap.1474, 2017.

Campana, S.: Chemistry and composition of fish otoliths:pathways, mechanisms and applications, Mar. Ecol. Prog. Ser., 188, 263297, https://doi.org/10.3354/meps188263, 1999.

Carnicer, J., Sardans, J., Stefanescu, C., Ubach, A., Bartrons, M., Asensio, D., Peñuelas, J., Civitello, D. J., Cohen, J., Fatima, H., Halstead, N. T., Liriano, J., McMahon, T. A., Ortega, C. N., Sauer, E. L., Sehgal, T., Young, S., Rohr, J. R., Rottstock, T., Joshi, J., Kummer, V., Fischer, M., Keesing, B. F., Ostfeld, R. S., Han, B. A., Schmidt, J. P., Bowden, S. E., Drake, J. M., Pimm, S. L., Jenkins, C. N., Abell, R., Brooks, T. M., Gittleman, J. L., Joppa, L. N., Raven, P. H., Roberts, C. M., and Sexton, J. O.: The biodiversity of species and their rates of extinction, distribution, and protection, Science, 344, 1246752, https://doi.org/10.1126/science.1246752, 2015.

Carvalho, F., Power, M., Forsberg, B. R., Castello, L., Martins, E. G., and Freitas, C. E. C.: Trophic Ecology of Arapaima sp. in a ria lake - river-floodplain transition zone of the Amazon, Ecol. Freshw. Fish., 27, 237-246, https://doi.org/10.1111/eff.12341, 2018.

Castello, L.: A method to count pirarucu Arapaima gigas: fishers, assessment, and management, North Am. J. Fish. Manag., 24, 379-389, https://doi.org/10.1577/M02-024.1, 2004.

Castello, L.: Lateral migration of Arapaima gigas in floodplains of the Amazon, Ecol. Freshw. Fish., 17, 38-46, https://doi.org/10.1111/j.1600-0633.2007.00255.x, 2008.

Castello, L. and Macedo, M. N.: Large-scale degradation of Amazonian freshwater ecosystems, Glob. Change Biol., 22, 990-1007, https://doi.org/10.1111/gcb.13173, 2016.

Castello, L., Mcgrath, D. G., Hess, L. L., Coe, M. T., Lefebvre, P. A., Petry, P., Macedo, M. N., Renó, V. F., and Arantes, C. C.: The 
vulnerability of Amazon freshwater ecosystems, Conserv. Lett., 6, 217-229, https://doi.org/10.1111/conl.12008, 2013.

Claverie, F., Fernández, B., Pécheyran, C., Alexis, J., and Donard, O. F. X.: Elemental fractionation effects in high repetition rate IR femtosecond laser ablation ICP-MS analysis of glasses, J. Anal. Atom. Spectrom., 24, 849-988, 2009.

Comyns, B. H., Rakocinski, C. F., Peterson, M. S., and Shiller, A. M.: Otolith chemistry of juvenile spotted seatrout Cynoscion nebulosus reflects local natal regions of coastal Mississippi, USA, Mar. Ecol. Prog. Ser., 371, 243-252, https://doi.org/10.3354/meps07604, 2008.

DeNiro, M. J. and Epstein, S.: Influence of diet on the distribution of carbon isotopes in animals, Geochim. Cosmochim. Ac., 42, 495-506, 1978.

Domingues, T. F., Crossa, N. M., Ometto, J. P. H. B., Martinelli, L. A., and Ehleringer, J. R.: Feeding history assessed from scales of two Amazonian fish using Carbon and Nitrogen stable isotopes, in preparation, 2006.

Duponchelle, F., Pouilly, M., Pécheyran, C., Hauser, M., Renno, J.F., Panfili, J., Darnaude, A. M., García-Vasquez, A., CarvajalVallejos, F., García-Dávila, C., Doria, C., Bérail, S., Donard, A., Sondag, F., Santos, R. V., Nuñez, J., Point, D., Labonne, M., and Baras, E.: Trans-Amazonian natal homing in giant catfish, edited by J. Heino, J. Appl. Ecol., 53, 1511-1520, https://doi.org/10.1111/1365-2664.12665, 2016.

Feio, T. A. and Mendes, G.: Commercialization of Fish at the Fairs of Manaus, Amazonia, During the Closed and Unclosed Seasons, Agr. Biol. Sci. J., 3, 7-11, 2017.

Figueiredo, E. S. A. (Org.): Biologia, conservação e manejo participativo de pirarucus na Pan - Amazônia, Tefé, IDSM, 278 pp., il. ISBN: 978-85-88758-29-2 1, 2013.

Finer, M. and Jenkins, C. N.: Proliferation of hydroelectric dams in the andean amazon and implications for andes-amazon connectivity, PLoS One, 7, 35126, https://doi.org/10.1371/journal.pone.0035126, 2012.

Forsberg, B. R., Araujo-Lima, C. A. R. M., Martinelli, L. A., Victoria, R. L., and Bonassi, J. A.: Autotrophic carbon sources for fish of the central Amazon, Ecology, 74, 643-652, https://doi.org/10.2307/1940793, 1993.

Forsberg, B. R., Melack, J. M., Dunne, T., Barthem, R. B., Goulding, M., Paiva, R. C. D., Sorribas, M. V, Silva, U. L., and Weisser, S.: The potential impact of new Andean dams on Amazon fluvial ecosystems, PLoS One, 12, 643-652, https://doi.org/10.1371/journal.pone.0182254, 2017.

Gaillardet, J., Dupré, B., Allegre, C. J., and Négrel, P.: Chemical and physical denudation in the Amazon River Basin, Chem. Geol., 142, 141-173, 1997.

Garcez, R. C. S., Humston, R., Harbor, D., and Freitas, C. E. C.: Otolith geochemistry in young-of-the-year peacock bass Cichla temensis for investigating natal dispersal in the Rio Negro (Amazon - Brazil) river system, Ecol. Freshw. Fish., 24, 242-251, https://doi.org/10.1111/eff.12142, 2015.

Gibbs, R. J.: The geochemistry of the Amazon River system: Part I. The factors that control the salinity and the composition and concentration of the suspended solids, Bull. Geol. Soc. Am., 78, 1203-1232, https://doi.org/10.1130/0016-7606, 1967.

Gillanders, B. M.: Temporal and spatial variability in elemental composition of otoliths: implications for determining stock iden- tity and connectivity of populations, Can. J. Fish. Aquat. Sci., 59, 669-679, https://doi.org/10.1139/f02-040, 2002.

Hauser, M.: Migração dos grandes bagres Amazônicos pela perspectiva dos isótopos de Estrôncio em otólitos, Universidade Federal de Rondônia (UNIR), 2018.

Hegg, J. C., Giarrizzo, T., and Kennedy, B. P.: Diverse early lifehistory strategies in migratory Amazonian catfish: Implications for conservation and management, PLoS One, 10, e0129697, https://doi.org/10.1371/journal.pone.0129697, 2015.

Hermann, T. W., Stewart, D. J., Limburg, K. E., and Castello, L.: Unravelling the life history of Amazonian fishes through otolith microchemistry, R. Soc. Open Sci., 3, 160206, https://doi.org/10.1098/rsos.160206, 2016.

Hrbek, T., Crossa, M., and Farias, I. P.: Conservation strategies for Arapaima gigas (Schinz, 1822) and the Amazonian várzea ecosystem, Braz. J. Biol., 67, 909-917, https://doi.org/10.1590/S1519-69842007000500015, 2007.

Jepsen, D. B. and Winemiller, K. O.: Basin geochemistry and isotopic ratios of fishes and basal production sources in four neotropical rivers, Ecol. Freshw. Fish., 16, 267-281, https://doi.org/10.1111/j.1600-0633.2006.00218.x, 2007.

Jordaan, L. J., Wepener, V., and Huizenga, J. M.: The strontium isotope distribution in water and fish within major South African catchments, Water SA, 42, 213-224, https://doi.org/10.4314/wsa.v42i2.05, 2016.

Junk, W., Bayley, P. B. and Sparks, R. E.: The flood pulse concept in river-floodplain-systems, Can. J. Fish. Aquat. Sci., 106, 110 127, https://doi.org/10.1371/journal.pone.0028909, 1989.

Kennedy, B. P., Folt, C. L., Blum, J. D., and Chamberlain, C. P.: Natural isotope markers in salmon, Nature, 387, 766-767, https://doi.org/10.1038/42835, 1997.

Kennedy, B. P., Blum, J. D., Folt, C. L., and Nislow, K. H.: Using natural strontium isotopic signatures as fish markers: methodology and application, Can. J. Fish. Aquat. Sci., 57, 2280-2292, https://doi.org/10.1139/f00-206, 2000.

Kennedy, B. P., Klaue, A., Blum, J. D., Folt, C. L., and Nislow, K. H.: Reconstructing the lives of fish using Sr isotopes in otoliths, Can. J. Fish. Aquat. Sci., 59, 925-929, https://doi.org/10.1139/f02-070, 2002.

Kennedy, B. P., Chamberlain, C. P., Blum, J. D., Nislow, K. H., and Folt, C. L.: Comparing naturally occurring stable isotopes of nitrogen, carbon, and strontium as markers for the rearing locations of Atlantic salmon (Salmo salar), Can. J. Fish. Aquat. Sci, 62, 48-57, https://doi.org/10.1139/F04-184, 2005.

Kerr, L. A. and Campana, S. E.: Chemical Composition of Fish Hard Parts as a Natural Marker of Fish Stocks, Stock Identif, Methods Appl. Fish. Sci., 2nd Edn., 1, 205-234, https://doi.org/10.1016/B978-0-12-397003-9.00011-4, 2013.

Kim, H., Suresh Kumar, K., and Shin, K. H.: Applicability of stable $\mathrm{C}$ and $\mathrm{N}$ isotope analysis in inferring the geographical origin and authentication of commercial fish (Mackerel, Yellow Croaker and Pollock), Food Chem., 172, 523-527, https://doi.org/10.1016/j.foodchem.2014.09.058, 2015.

Latrubesse, E. M., Arima, E. Y., Dunne, T., Park, E., Baker, V. R., D'Horta, F. M., Wight, C., Wittmann, F., Zuanon, J., Baker, P. A., Ribas, C. C., Norgaard, R. B., Filizola, N., Ansar, A., Flyvbjerg, B., and Stevaux, J. C.: Damming the rivers of the Amazon basin, Nature, 546, 363-369, https://doi.org/10.1038/nature22333, 2017. 
Lees, A. C., Peres, C. A., Fearnside, P. M., Schneider, M., Jansen, and Zuanon, A. S.: Hydropower and the future of Amazonian biodiversity, Biodivers. Conserv., 25, 451-466, https://doi.org/10.1007/s10531-016-1072-3, 2016.

Li, L., Boyd, C. E., and Sun, Z.: Authentication of fishery and aquaculture products by multi-element and stable isotope analysis, Food Chem., 194, 1238-1244, https://doi.org/10.1016/j.foodchem.2015.08.123, 2016.

Marshall, B. G., Forsberg, B. R., and Thomé-Souza, M. J. F.: Autotrophic energy sources for Paracheirodon axelrodi (Osteichthyes, Characidae) in the middle Negro River, Central Amazon, Brazil, Hydrobiologia, 596, 95-103, https://doi.org/10.1007/s10750-007-9060-y, 2008.

McGrath, D. G., Castello, L., Almeida, O. T., and Estupiñán, G. M. B.: Market Formalization, Governance, and the Integration of Community Fisheries in the Brazilian Amazon, Soc. Nat. Resour., 28, 513-529, https://doi.org/10.1080/08941920.2015.1014607, 2015.

Miranda-Chumacero, G., Wallace, R., Calderón, H., Calderón, G., Willink, P., Guerrero, M., Siles, T., Lara, K., and Chuqui, D.: Distribution of arapaima (Arapaima gigas) (Pisces: Arapaimatidae) in Bolivia: implications in the control and management of a non-native population, BioInvasions Rec., 1, 129-138, https://doi.org/10.3391/bir.2012.1.2.09, 2012.

Mortillaro, J. M., Pouilly, M., Wach, M., Freitas, C. E. C., Abril, G., and Meziane, T.: Trophic opportunism of central Amazon floodplain fish, Freshw. Biol., 60, 1659-1670, https://doi.org/10.1111/fwb.12598, 2015.

Núñez-Rodríguez, J., Duponchelle, F., Cotrina-Doria, M., Renno, J. F., Chavez-Veintimilla, C., Rebaza, C., Deza, S., García-Dávila, C., Chu-Koo, F., Tello, S., and Baras, E.: Movement patterns and home range of wild and re-stocked Arapaima gigas (Schinz, 1822) monitored by radio-telemetry in Lake Imiria, Peru, J. Appl. Ichthyol., 31, 10-18, https://doi.org/10.1111/jai.12972, 2015.

Oliveira, A. C. B., Soares, M. G. M., Martinelli, L. A., and Moreira, M. Z.: Carbon sources of fish in an Amazonian floodplain lake, Aquat. Sci., 68, 229-238, https://doi.org/10.1007/s00027006-0808-7, 2006.

Oliveira, E.: Les régimes hydrologiques de 1 ' Amazone et de ses affluents, L'hydrologie Trop. géoscience Outil. développement, available at: https://www.researchgate.net/publication/32971568 (last access: 24 September 2018), 1996.

Ono, E. A. and Kehdi, J.: Manual de Boas Práticas de Produção do Pirarucu em Cativeiro, Brasília, 2013.

Palmer, M. and Edmond, J.: Controls over the strontium isotope composition of river water, Geochim. Cosmochim. Ac., 56, 2099-2111, https://doi.org/10.1016/0016-7037(92)90332-D, 1992.

Payan, P., Pontual, H. De, Edeyer, A., Borelli, G., Boeuf, G., and Mayer-Gostan, N.: Effects of stress on plasma homeostasis, endolymph chemistry, and check formation during otolith growth in rainbow trout (Oncorhynchus mykiss), Can. J. Fish. Aquat. Sci., 61, 1247-1255, https://doi.org/10.1139/f04-059, 2004.

Pereira, L. A., Pouilly, M., Ventura Santos, R., and Hauser, M.: Commercial traceability of Arapaima spp. fisheries in the Amazon basin: can biogeochemical tags be useful?, available at: https://doi.org/10.5281/zenodo.2646436, last access: 19 April 2019.
Pouilly, M., Point, D., Sondag, F., Henry, M., and Santos, R. V.: Geographical origin of Amazonian freshwater fishes fingerprinted by ${ }^{87} \mathrm{Sr} /{ }^{86} \mathrm{Sr}$ ratios on fish otoliths and scales, Environ. Sci. Technol., 48, 8980-8987, https://doi.org/10.1021/es500071w, 2014.

Pracheil, B. M., Hogan, J. D., Lyons, J., and McIntyre, P. B.: Using Hard-Part Microchemistry to Advance Conservation and Management of North American Freshwater Fishes, Fisheries, 39, 451-465, https://doi.org/10.1080/03632415.2014.937858, 2014.

Queiroz, H. L.: Natural History And Conservation Of Pirarucu,Arapaima gigas, at The Amazonian Varzea: Red Giants In Muddy Waters, University of St. Andrews, 2000.

Radtke, R. L., Lenz, P., Showers, W., and Moksness, E.: Environmental information stored in otoliths: insights from stable isotopes, Mar. Biol., 127, 161-170, https://doi.org/10.1007/BF00993656, 1996.

Rojas, J. M. M., Serra, F., Giani, I., Moretti, V. M., Reniero, F., and Guillou, C.: The use of stable isotope ratio analyses to discriminate wild and farmed gilthead sea bream (Sparus aurata), Rapid Commun. Mass. Sp., 21, 207-211, https://doi.org/10.1002/rcm.2836, 2007.

Sant'Ana, L. S., Ducatti, C., and Ramires, D. G.: Seasonal variations in chemical composition and stable isotopes of farmed and wild Brazilian freshwater fish, Food Chem., 122, 74-77, https://doi.org/10.1016/j.foodchem.2010.02.016, 2010.

Santos, R. V., Sondag, F., Cochonneau, G., Lagane, C., Brunet, P., Hattingh, K., and Chaves, J. G. S.: Source area and seasonal ${ }^{87} \mathrm{Sr} /{ }^{86} \mathrm{Sr}$ variations in rivers of the Amazon basin, Hydrol. Process., 29, 187-197, https://doi.org/10.1002/hyp.10131, 2015.

Sousa, R. G. C., Humston, R., and Freitas, C. E. C.: Movement patterns of adult peacock bass Cichla temensis between tributaries of the middle Negro River basin (Amazonas - Brazil): an otolith geochemical analysis, Fish. Manag. Ecol., 23, 76-87, https://doi.org/10.1111/fme.12166, 2016.

Stallard, R. F.: Major element geochemistry of the amazon river system, Massachusetts Institute of Technology, woods Hole Oceanographic Institution, 1980.

Stallard, R. F. and Edmond, J. M.: The Influence of Geology and Weathering Environment on the Dissolved Load, J. Geophys. Res., 88, 9671-9688, 1983.

Stewart, D. J.: A New Species of Arapaima (Osteoglossomorpha: Osteoglossidae) from the Solimões River, Amazonas State, Brazil, Copeia, 2013, 470-476, https://doi.org/10.1643/CI-12017, 2013a.

Stewart, D. J.: Re-description of Arapaima agassizii (Valenciennes), a Rare Fish from Brazil (Osteoglossomorpha: Osteoglossidae), Copeia, 2013, 38-51, https://doi.org/10.1643/CI-12-013, 2013 b.

Stone, R.: The last of the leviathans, Science, 316, 1684-1688, https://doi.org/10.1126/science.316.5832.1684, 2007.

Sturrock, A. M., Trueman, C. N., Darnaude, A. M., and Hunter, E.: Can otolith elemental chemistry retrospectively track migrations in fully marine fishes?, J. Fish Biol., 81, 766-795, https://doi.org/10.1111/j.1095-8649.2012.03372.x, 2012.

Sturrock, A. M., Trueman, C. N., Milton, J. A., Waring, C. P., Cooper, M. J., and Hunter, E.: Physiological influences can outweigh environmental signals in otolith microchemistry research, Mar. Ecol. Prog. Ser., 500, 245-264, https://doi.org/10.3354/meps10699, 2014. 
Tabouret, H., Bareille, G., Claverie, F., Pécheyran, C., Prouzet, P., and Donard, O. F. X.: Simultaneous use of strontium:calcium and barium:calcium ratios in otoliths as markers of habitat: Application to the European eel (Anguilla anguilla) in the Adour basin, South West France, Mar. Environ. Res., 70, 35-45, https://doi.org/10.1016/J.MARENVRES.2010.02.006, 2010.

Thresher, R. E.: Elemental composition of otholits as a stock delineator in fishes, Fish. Res., 43, 165-204, 1999.

Turchini, G. M., Quinn, G. P., Jones, P. L., Palmeri, G., and Gooley, G.: Traceability and Discrimination among Differently Farmed Fish?: A Case Study on Australian Murray Cod Traceability and Discrimination among Differently Farmed Fish?: A Case Study on Australian Murray, Society, 274-281, https://doi.org/10.1021/jf801962h, 2009.

Van Damme, P. A., Carvajal-Vallejos, F. M., and Carpio, J. M. (Eds.): Los peces y delfines de la Amazonía boliviana: hábitats, potencialidades y amenazas, INIA, Cochabamba, Bolivia, 490 pp., available at: http://www.editorial-inia.com (last access: 22 October 2018), 2011.

Viana, J. P., Castello, L., Damasceno, J. M. B., Amaral, E. S., Estupiñan, G. M., Arantes, C., Batista, G. S., Garcez, D. S., and Barbosa, S.: Manejo Comunitário do Pirarucu Arapaima gigas na Reserva de Desenvolvimento Sustentável Mamirauá-Amazonas, Brasil, Áreas aquáticas protegidas como instrumento de gestão pesqueira, Série Áreas Protegidas do Brasil, 4, 239-261, 2007.

Walther, B. D. and Thorrold, S. R.: Water, not food, contributes the majority of strontium and barium deposited in the otoliths of a marine fish, Mar. Ecol. Prog. Ser., 311, 125-130, https://doi.org/10.3354/meps311125, 2006.
Walther, B. D. and Thorrold, S. R.: Continental-scale variation in otolith geochemistry of juvenile American shad (Alosa sapidissima), Can. J. Fish. Aquat. Sci., 65, 2623-2635, https://doi.org/10.1139/F08-164, 2008.

Walther, B. D., Dempster, T., Letnic, M., Mcculloch, M. T., and Unsworth, R. K. F.: Movements of Diadromous Fish in Large Unregulated Tropical Rivers Inferred from Geochemical Tracers, PLoS One, 6, e18351, https://doi.org/10.1371/journal.pone.0018351, 2011.

Watson, L. C., Stewart, D. J., and Teece, M. A.: Trophic ecology of Arapaima in Guyana: Giant omnivores in Neotropical floodplains, Neotrop. Ichthyol., 11, 341-349, https://doi.org/10.1590/S1679-62252013000200012, 2013.

Winemiller, K. O., McIntyre, P. B., Castello, L., Fluet-Chouinard, E., Giarrizzo, T., Nam, S., Baird, I. G., Darwall, W., Lujan, N. K., Harrison, I., Stiassny, M. L. J., Silvano, R. A. M., Fitzgerald, D. B., Pelicice, F. M., Agostinho, A. A., Gomes, L. C., Albert, J. S., Baran, E., Petrere, M., Zarfl, C., Mulligan, M., Sullivan, J. P., Arantes, C. C., Sousa, L. M., Koning, A. A., Hoeinghaus, D. J., Sabaj, M., Lundberg, J. G., Armbruster, J., Thieme, M. L., Petry, P., Zuanon, J., Vilara, G. T., Snoeks, J., Ou, C., Rainboth, W., Pavanelli, C. S., Akama, A., and Sáenz, L. S.: Sustainable water management under future uncertainty with eco-engineering decision scaling, Nat. Clim. Change, 6, 25-34, https://doi.org/10.1038/nclimate2765, 2016.

Woodhead, J., Swearer, S., Hergt, J., and Maas, R.: In situ Sr-isotope analysis of carbonates by LA-MC-ICP-MS: interference corrections, high spatial resolution and an example from otolith studies, J. Anal. Atom. Spectrom., 20, 22-27, https://doi.org/10.1039/b412730g, 2005. 